AperTO - Archivio Istituzionale Open Access dell'Università di Torino

Integrated stratigraphy and paleoceanographic evolution of the pre-evaporitic phase of the Messinian salinity crisis in the Eastern Mediterranean as recorded in the Tokhni section (Cyprus island)

This is a pre print version of the following article:

Original Citation:

Availability:

This version is available http://hdl.handle.net/2318/1661639

since 2018-03-08T09:14:58Z

Published version:

DOI:10.1127/nos/2017/0350

Terms of use:

Open Access

Anyone can freely access the full text of works made available as "Open Access". Works made available under a Creative Commons license can be used according to the terms and conditions of said license. Use of all other works requires consent of the right holder (author or publisher) if not exempted from copyright protection by the applicable law. 


\title{
Integrated stratigraphy and paleoceanographic evolution of the pre-evaporitic phase of the Messinian salinity crisis in the Eastern Mediterranean as recorded in the Tokhni section (Cyprus island)
}

\author{
Rocco Gennari ${ }^{1,2,3 *}$, Francesca Lozar ${ }^{3}$, Elena Turco', ${ }^{1}$ Francesco Dela Pierre ${ }^{3}$, \\ Stefano Lugli ${ }^{5}$, Vinicio Manzi $i^{1,2}$, Marcello Natalicchio ${ }^{3,4}$, Marco Roveri ${ }^{1,2}$, \\ B. Charlotte Schreiber ${ }^{6}$, and Marco Taviani ${ }^{7,8,9}$
}

With 8 figures

\begin{abstract}
An integrated micropaleontologic, magnetostratigraphic and cyclostratigraphic investigation of the Tokhni composite section (Southern Cyprus Island, Eastern Mediterranean) refines the previously published age model and paleoenvironmental interpretation particularly concerning its uppermost pre-Messinian Salinity Crisis interval (pre-MSC), between 6.46 and $5.97 \mathrm{Ma}$. This section is characterized by a precessionpaced alternation of red shales and limestones, which correlate with insolation maxima and minima on the basis of their $\delta^{18} \mathrm{O}$ signatures and calcareous nannofossil assemblages. The planktonic foraminifer and magnetostratigraphic events permit the tuming of the sedimentary cycles to the $65^{\circ} \mathrm{N}$ summer insolation curve and to the Mediterranean pre-evaporitic reference sections. The upper bathyal sedimentary succession of the Tokhni composite section records paleoceanographic changes at 6.4 and $6.1 \mathrm{Ma}$, indicating increasingly stressed conditions both at the sea floor and in the water column. Compared to the Western Mediterranean pre-MSC successions, we observe less severe sea floor anoxic conditions at times of insolation maxima and higher salinity surface and bottom waters at times of insolation minima. Moreover, from 6.1 Ma to the MSC onset we observe a progressively increase of continental-derived waters, which was likely caused by a tec-
\end{abstract}

\footnotetext{
Authors' addresses:

1 Physics and Earth Science Department, University of Parma, Parco Area delle Scienze, 157/A 43124 Parma, Italy. rocco.gennari@gmail.com, elena.turco@unipr.it, vinicio.manzi@unipr.it, marco.roveri@unipr.it

2 ALP, Alpine Laboratory of Palaeomagnetism, Via G. U.Luigi Massa, 6, 12016 Peveragno, Cuneo, Italy.

3 Earth Science Department, University of Turin, Via T. Valperga Caluso, 35, 10125, Torino, Italy. francesca.lozar@unito.it, francesco.delapierre@unito.it,marcello.natalicchio@unito.it

4 Institute of Geology, University of Hamburg, Bundesstraße 55, 20146 Hamburg, Germany.

5 Chemical and Geological Department, University of Modena and Reggio Emilia, Campus Scientifico, Via G.Campi, 183, 41125 Modena, Italy. stefano.lugli@unimore.it

6 Department of Earth and Space Sciences, University of Washington, Johnson Hall Rm-070, $400015^{\text {th }}$ Avenue NE, Seattle, WA 98195-1310, USA.geologo1@u.washington.edu

7 ISMAR-CNR, Via Gobetti 101, 40129 Bologna, Italy. marco.taviani@bo.ismar.cnr.it

8 Biology Department, Woods Hole Oceanographic Institution, 266 Woods Hole Rd, Woods Hole, MA 02543, USA.

9 Stazione Zoologica Anton Dohrn, Villa Comunale, 80121 Napoli, Italy.

* Corresponding author: rocco.gennari@gmail.com
} 
tonic pulse. The MSC onset at $5.97 \mathrm{Ma}$ is marked by the deposition of clastic carbonates rather than primary evaporitic facies and is approximated by the last recovery of foraminifera, the abundance peaks of Helicosphaera carteri and Umbilicosphaera rotula and the decrease of the ${ }^{87 / 86} \mathrm{Sr}$. The MSC onset is recorded two cycles below the Messinian erosional surface (MES, 5.60 Ma) and the overlying clastic evaporites, suggesting a hiatus of approximately $350 \mathrm{kyr}$.

Key words. Eastern Mediterranean, Messinian, calcareous nannofossils, foraminifera, integrated stratigraphy, paleoenvironment

\section{Introduction}

The pre-evaporitic phase of the Messinian salinity crisis (MSC) was characterized by marked paleoceanographic changes culminating in the deposition of huge volume of evaporites in the shallow and deep/intermediate settings of the Mediterranean basin during stage 1 (from 5.971 Ma; Manzi et al. 2013) and stage 2 (from $5.60 \mathrm{Ma}$; Roveri et al. 2009), respectively. The major steps of this paleoceanographic evolution occurred at 7.16, 6.7 , 6.4-6.29 and 6.1-6.0 Ma (see Kouwenhoven et al. 2006, with references therein). Each of these steps was conducive to increasingly stressing conditions both at the sea floor and in the water column, as documented by the progressive increase of oligotypic calcareous plankton and benthic foraminifer assemblages. The first two steps were related to the tectonic narrowing and/or closure of the Atlantic connections in the Rifian corridors (Krijgsman et al. 1999a and b, Krijgsman and Langereis 2000), which caused the slowing or stopping of the Mediterranean deep circulation. However, Blanc-Valleron et al. (2002) noted that these paleoceanographic steps roughly follow the $400 \mathrm{kyr}$ eccentricity cycle, and Kouwenhoven et al. (2006) also suggested a relation between the increasing restriction of the deep circulation and this orbital parameter. In addition, the restricted connections with the Atlantic from 7.16 Ma increased the sensitivity of the Mediterranean basin to record the precession-controlled climatic changes resulting in a more regular formation of sapropels at times of precession minima (Sierro et al. 2003).

In the deep- and intermediate-water successions, such as at Monte del Casino (northern Apennines, Italy) and Pissouri (southern Cyprus) sections, respectively (Kouwenhoven et al. 2003; Kouwenhoven et al. 2006), the step at 7.16 Ma was characterized by the disappearance of oxyphilic benthic foraminifera and the increase of taxa tolerating low oxygen levels and raised salinity (Van der Zwaan 1982, Kouwenhoven et al. 1999). As seen in the Gibliscemi-Falconara sections (Sicily), the central Mediterranean was more severely affected by the reduced deep-water circulation, marked by a temporarily disappearance of benthic foraminifera (Kouwenhoven et al. 2003). Moreover, diatomite beds started to deposit in the Mediterranean between 7.16 and 6.7 Ma (Pestrea et al. 2002), indicating a significant availability of silica at times of enhanced eutrophication, likely connected to upwelling episodes during insolation minima (Sierro et al. 2003, Flores et al. 2005).

Beginning at $6.7 \mathrm{Ma}$ (second step), not only the benthic foraminifera show an abundance increase of stress tolerant taxa (indicating low oxygen and/or raised salinity bottom conditions) and are absent in sapropels (Sierro et al. 2003, Kouwenhoven et al. 2006), but also the calcareous plankton assemblages are characterized by reduced diversity and abundance (Sierro et al. 2003). Moreover, an increased response to the insolation fluctuations is highlighted by the dominance of cold/eutrophic calcareous plankton taxa at times of insolation minima and warm/oligotrophic taxa at times of insolation maxima (Blanc-Valleron et al. 2002, Sierro et al. 2003, Flores et al. 2005). It is worth noting that changes in calcareous plankton assemblages from 6.7 Ma equally affected both deep and shallow successions.

From 6.4 Ma the Plankton/Benthos ratio shows abrupt fluctuations, with values ranging from $100 \%$ to near $0 \%$, indicating the occurrence of a-benthic foraminiferal layers due to anoxic conditions during insolation maxima and of strongly reduced/a-planktonic layers (insolation minima) (Sierro et al. 2003). In the superficial waters, the presence of oligotypic assemblages dominated by Turborotalia quinqueloba and T. multiloba (up to $80 \%$ ) during insolation minima are usually related to increased salinity corresponding to very arid climatic phases (Sierro et al. 2003, Kouwenhoven et al. 2006).

The last step at 6.1-6.0 Ma certifies the final decrease of calcareous microfossils, whose disappearance approximates the MSC onset at 5.971 Ma (Manzi et al. 2007, Lozar et al. 2010, Manzi et al. 2011, Manzi et al. 2013). 
The eastern Mediterranean pre-evaporitic (preMSC) micropaleontologic record has been mainly studied onshore of Cyprus and Crete (Van der Zwaan 1982, Triantaphyllou et al. 1999, Kouwenhoven et al. 2006, Drinia et al. 2007, Orszag-Sperber et al. 2009). On the southern part of the Cyprus Island, an integrated stratigraphy was obtained for the Tokhni and Pissouri sections (Krijgsman et al. 2002, Orszag-Sperber et al. 2009), located in the Psematismenos and the Pissouri basins (Fig. 1), respectively. These two sections were correlated with the Perales reference section (Sorbas basin) for the western Mediterranean (Sierro et al. 2001) by means of biomagnetostratigraphic and cyclostratigraphic constraints. Overall, the paleoceanographic evolution observed in the Cyprus basin is similar to that envisaged in the western Mediterranean, although the pre-MSC sedimentary successions differ for the scarce presence or absence of sapropels and for the occurrence of chaotic/carbonate deposits ("barre jaune") just below the lowermost gypsum bed (Kouwenhoven et al. 2006, Orszag-Sperber et al. 2009). Moreover, the identification of the MSC onset in these sections has been debated. According to Krijgsman et al. (2002) and Kouwenhoven et al. (2006) it is represented by the lowermost gypsum bed in the Pissouri section. Differently, according to Orszag-Sperber et al. (2009), it coincides in the Tokhni section with the basal stromatolitic bed of the "barre jaune" and, consequently, the deposition of the lowermost gypsum bed is delayed by 60 kyrs. Both these interpretations have been questioned by Manzi et al. (2016) based on sedimentologic and stratigraphic evidences. These authors stated that on Cyprus the Primary Lower Gypsum (PLG, Roveri et al. 2009) of the $1^{\text {st }}$ stage of the MSC are lacking, whereas the gypsum deposits are clastic facies floored by an angular unconformity likely corresponding to the Messinian erosional surface (MES). Thus, the gypsum unit of the Tokhni section has been ascribed to the stage 2 of the MSC (Roveri et al. 2009). Consequently, Manzi et al. (2016) suggested that the MSC onset is best approximated by the last occurrence of foraminifera, identified within the interval corresponding to the "barre jaune" of Orszag-Sperber et al. (2009).

Here we present a reinvestigation of the upper part of the Tokhni section producing an updated calcareous plankton biostratigraphy and cyclostratigraphy, validated by new magnetostratigraphic data. The micropaleontologic and isotopic data, supported by the new age model and integrated with the stratigraphic and sedimentologic evidences as presented in Manzi et al. (2016), allowed the reconstruction of the paleoenvironmental and paleoceanographic evolutions in the Psematismenos basin during the pre-MSC and their comparison with those of the central and western Mediterranean successions.

\section{Geological setting and section}

The Tokhni composite section is exposed in the badlands $1 \mathrm{~km}$ southwest from the village of Tokhni (southern Cyprus Island), located at the southeastern termination of the Troodos Massif, in the Psematismenos basin (Fig. 1). The composite section combines 4 sub-sections (To-0, To-1, To-2 and To-3; Fig. 2; Manzi et al. 2016), and comprises the upper part of the Pakhna Formation (Bagnall 1960, Gass 1960, Pantazis 1967), and the evaporites of the Kalavasos Formation. Here we follow the subdivision of the Pakhna Formation into four subunits (from the bottom, PK- $\mathrm{A}_{1}, \mathrm{PK}-\mathrm{A}_{2}, \mathrm{PK}-\mathrm{A}_{3}$ and PK-B) as proposed by Manzi et al. (2016) (Fig. 2).

1) Sub-unit PK- $A_{1}$ - It consists of m-thick alternation of darker and lighter homogeneous blue marls. Orszag-Sperber et al. (2009) recognized the TortonianMessinian boundary in the upper part of this sub-unit
Fig. 1. A) Generalized geological map of the central and eastern Mediterranean and B) of the southwestern portion of the Cyprus Island with the indication of the position of the Tokhni (Orszag-Sperber et al. 2009, Manzi et al. 2016, this study) and Pissouri (Krijgsman et al. 2002, Kouwenohven et al. 2006) sections.

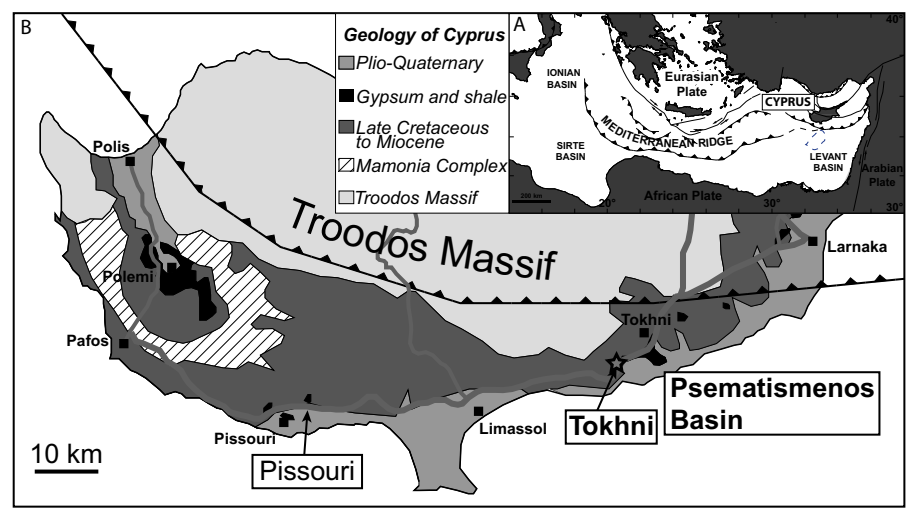


on the basis of the first occurrence of the planktonic foraminifer Globorotalia miotumida.

2) Sub-unit PK-A - It is characterized by a lithologic cyclic stacking pattern formed by an alternation of prominent marls and reddish shales.

3) Sub-unit PK- $A_{3}-$ It is mainly characterized by a cyclic alternation of reddish shales and whitish micritic limestones, and its base is marked by a $80 \mathrm{~cm}$-thick whitish limestone bed. However, from ca. $15 \mathrm{~m}$ above the base of this sub-unit, marl layers and/or slightly prominent pink diatomitic layers are associated with or replace the whitish limestone within the basic cycle. Diatomites are particularly common in the upper part of this sub-unit and within the upper PK-B sub-unit (see below). The micritic limestone layers, in particular the lowermost one, are laterally continuous and easily detectable in the field, and were used as keybeds in the reconstruction of the composite section (Fig.2). These layers are made up of a mixture of clay and coccoliths cemented by micron-sized calcite crystals (Manzi et al. 2016). Another useful key-bed observed in the upper part of this sub-unit is a thin conglomerate layer (thickness $25-40 \mathrm{~cm}$ ), showing an erosive base. This layer is entirely made up of limestone-derived pebbles floating in a bioclastic packstone matrix; the latter contains planktonic and benthic foraminifera, siliceous sponge spicules, echinoid spines and fragments of coralline algae. Sparse siltsize terrigenous grains are also present.

4) Sub-unit PK-B - This uppermost sub-unit has been recognized only in the southern subsections To-2 and To-3. It is characterized by the presence of 3 limestone beds (indicated as A, B and C) showing different characteristics with respect to the limestones of subunit PK- $\mathrm{A}_{3}$ and intercalated by reddish shales and pink diatomites. These limestone beds belong to the "barre jaune" described in the Tokhni section by Orszag-Sperber et al. (2009), who interpreted them as precessioncontrolled stromatolites suggesting periodical shallowing and drying up of the basin. Differently, Manzi et al. (2016) did not recognize evidences of shallowing or drying up. According to these authors the lower part of the limestone A is a finely laminated microbialite and contains cavities possibly indicating the displacive growth of sub-millimetric gypsum crystals, successively replaced by micrite. The upper part of limestone A shows penecontemporaneous reworking of the microbialite by subaqueous gravity flows. The two uppermost limestone layers (B and C) show completely different characteristics and internal organization. They are made up of coarse-grained clastic sediments, grain- stone and rudstone likely deriving from the dismantlement of a penecontemporaneous carbonate platform forming in the Tokhni area (Robertson et al. 1995).

The boundary between the Pakhna and the Kalavasos formations is sharp and discordant. In fact, as described in Manzi et al. (2016), the uppermost part of the Pakhna Formation shows from south to north: i) the disappearance of the PKB sub-unit; ii) a progressive truncation of the $\mathrm{PK}-\mathrm{A}_{3}$ sub-unit (Fig.2); iii) a steeper inclination of the base of the evaporites of Kalavasos Formation with respect to the Pakhna Formation. Accordingly, the base of the Kalavasos Formation is an angular unconformity and coincides with the Messinian erosional surface (MES); indeed, these evaporites are clastic and belong to the Resedimented Lower Gypsum (RLG, Roveri et al. 2009) unit deposited during stage 2 , rather than representing the Primary Lower Gypsum (PLG of Roveri et al. 2009) of stage 1, as previously argued by Orszag-Sperber et al. (2009). In the present study we focus on the upper part of the Tokhni composite section, corresponding to subunits PK-A 3 and PK-B.

\section{Material and Methods}

\subsection{Magnetostratigraphy}

A total of 16 samples were collected in the subsection To-1 (10-31.5 m interval of the composite section; Fig. 2), mainly from the limestone beds, due to the pervasive fracture of the shales and lamination of the diatomites. Samples were thermally demagnetized in an ASC electric hoven at the Alpine Laboratory of Paleomagnetism (Alp, Peveragno, Italy) and were initially heated at $100^{\circ} \mathrm{C}$ and then up to $340-450^{\circ} \mathrm{C}$, by successive increasing steps of $30^{\circ} \mathrm{C}$. At each step we measured the remanent magnetization in a $2 \mathrm{G}-$ Enterprises DC SQUIDS cryogenic magnetometer, and the magnetic susceptibility to check for thermal alteration of the magnetic mineralogy. The NRM data were processed with the Remasoft software (Chadima and Hrouda 2006), which computed the principal component analysis of the linear vector (Kirschvink 1980) picked from orthogonal projection demagnetization diagrams (Zijderveld 1967) to obtain the characteristic remanent magnetization (ChRM).

\subsection{Foraminifera}

The 87 samples collected from subsections To-1, To-2 and To-3 (Fig. 2) were dried and then soaked in diluted 


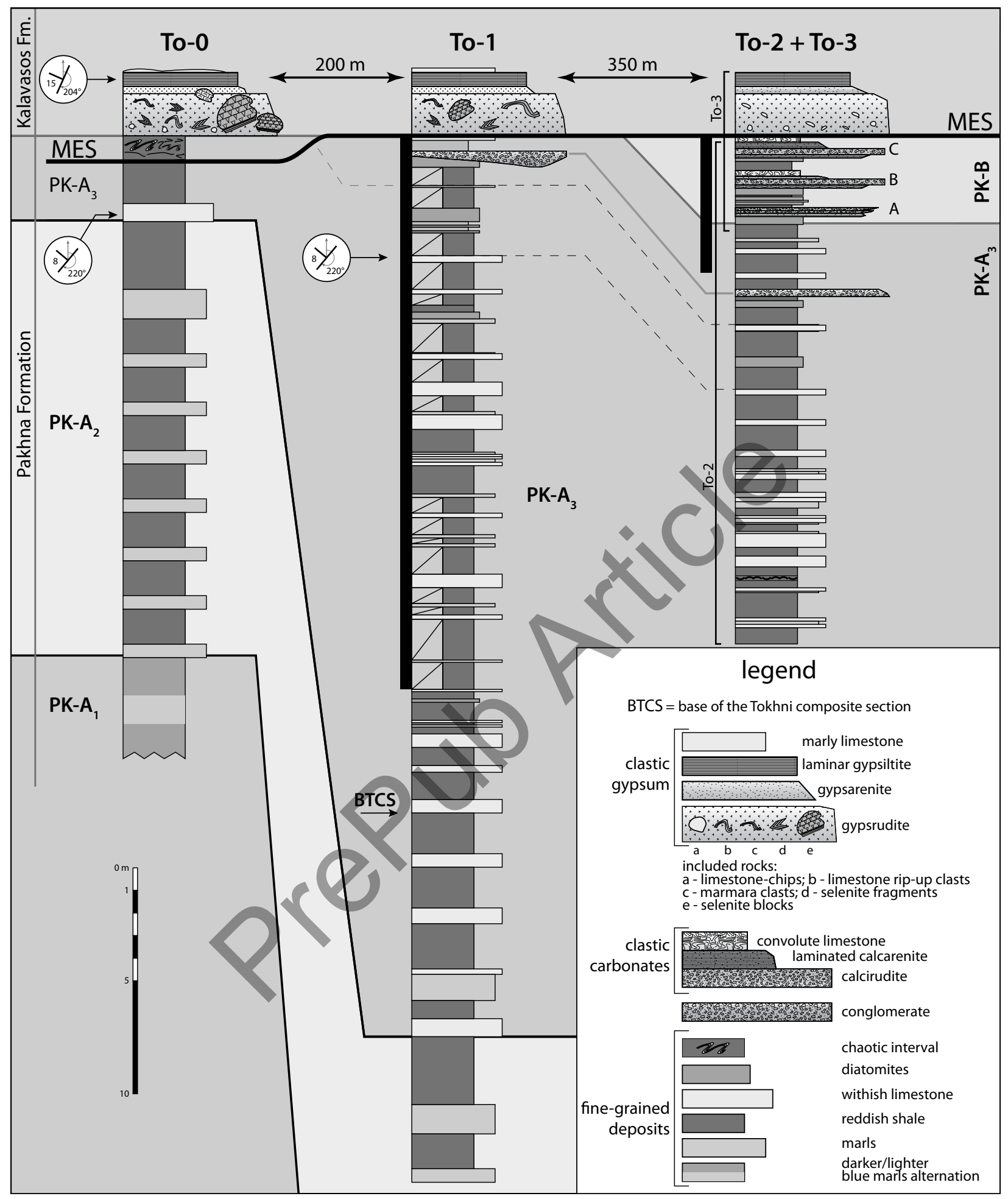

Fig. 2. Lithological log of the four sub-sections outcropping near the Tokhni village. The dip and the inclination of the strata in the Pakhna and Kalavasos Formations are shown in order to highlight the presence of an unconformity related to the Messinian erosional surface (MES). The base of the Tokhni composite section (BTCS) is indicated with an arrow in subsection To-1. The black bar next to sub-sections To-1, 2 and 3 shows the interval sampled for the quantitative calcareous nannofossil analysis and semi-quantitative foraminifer analysis. 
$\mathrm{H}_{2} \mathrm{O}_{2}$ for a few days; successively, they were washed using a $63 \mu \mathrm{m}$ mesh, dried again and sieved to obtain the study fraction $(>125 \mu \mathrm{m})$. The planktonic foraminifer record of the Tokhni section is biased by several problems: a) reworking of Eocene to middle Miocene specimens (see also Orszag-Sperber et al. 2009) is present in the PK- $\mathrm{A}_{2}$ and lower part of PK- $\mathrm{A}_{3}$ sub-units, up to $7 \mathrm{~m}$ of the composite section and it gradually decreases upward; b) in the 0-28 m interval the foraminifer abundance is highly variable and roughly decreases from the bottom to the top; in particular, the most prominent limestones starting from $11.5 \mathrm{~m}$ are barren of both benthic and planktonic foraminifera; c) inorganic particles (terrigenous grains, un-disaggregated sediment, etc.) represent a large portion of the washed residues; d) preservation is generally poor. For these reasons qualitative observations were performed on the samples collected from PK- $\mathrm{A}_{2}$ and lower part of PK- $\mathrm{A}_{3}$ subunits. A semi-quantitative analysis of selected taxa was carried out on 48 out of 60 samples collected from PK- $\mathrm{A}_{3}$ and PK-B sub-units (from $7 \mathrm{~m}$ upward of the Tokhni composite section, see Fig. 2), avoiding samples barren in foraminifera (limestones) and samples characterized by very diluted foraminiferal content and/or very poor preservation. Among planktonic foraminifera, all the Globigerina, Globigerinoides and Globigerinita species were respectively clustered as genera; however, Globigerina bulloides is largely predominant within the Globigerina gr., and Globigerinita glutinata within the Globigerinita gr. Sinistrally and dextrally coiled Neogloboquadrina acostaensis were counted separately. Bolivinids, buliminids and elphidiids were considered as generic groups among benthic foraminifera. A group of taxa showing low abundances and including Hanzawaia boueana, Cancris oblungus, Valvulineria complanata, Rosalina globularis and Ammonia sp. were lumped together as "inner shelf taxa". Each selected taxon was picked and counted at maximum in 9 fields (out of 45) of a standard picking tray if not exceeding 30 specimens. The total abundance of planktonic and benthic foraminifera and the abundance of the selected taxa were then normalized to one field and plotted against the stratigraphic height. We also calculated the $\mathrm{P} / \mathrm{B}$ ratio as $\mathrm{P} *(\mathrm{P}+\mathrm{B}) / 100$, where $\mathrm{P}$ and $\mathrm{B}$ represent the total number of planktonic foraminifera and benthic foraminifera per field, respectively.

\subsection{Calcareous nannofossils}

Calcareous nannofossil assemblages from 60 out of 87 samples collected in the Tokhni composite section within PK-A $\mathrm{A}_{3}$ and PK-B sub-units (8-36.5 m; Figs. 2, and 5) were studied in smear slides with a microscope at 1250X under cross polarized light microscope. Slide preparation was kept simple using standard techniques in order to retain the original composition of the sediment (Bown and Young 1998). Only the uppermost samples were barren of calcareous nannofossils. Quantitative analyses were carried out by counting at least 500 specimens per sample and relative abundances are expressed in $\%$ of the total assemblage. Abundance percentages of significant taxa were plotted against their stratigraphic level. Frequencies of very rare and biostratigraphically significant genera (Amaurolithus, Discoaster) were estimated by counting the number of specimens in 500 fields of view, corresponding to an area of $11250 \mathrm{~mm}^{2}$. Abundances of these taxa are expressed in $\mathrm{n} / \mathrm{mm}^{2}$. Discoaster spp. were identified at the species level, nevertheless, due to the very low abundance of D. surculus, we lumped D. surculus and D.variabilis into the Discoaster variabilis group.

\subsection{Isotopic geochemistry}

\subsubsection{Oxygen and Carbon stable isotopes}

Stable oxygen and carbon isotope composition of 79 bulk samples were measured in the Geochemistry Laboratory of the Physical and Earth Science Department of the University of Parma. The isotopic composition of calcite samples (originating from micritic crystals, foraminifera and calcareous nannofossils) was obtained from the reaction of the powdered carbonate with $100 \% \mathrm{H}_{3} \mathrm{PO}_{4}$ "in vacuo" and under controlled temperature $\left(25^{\circ} \mathrm{C}\right)$. The isotopic composition of $\mathrm{CO}_{2}$ samples was measured on a Finnigan Delta $\mathrm{S}$ mass spectrometer against a $\mathrm{CO}_{2}$ standard gas obtained by the reaction at $25^{\circ} \mathrm{C}$ of very pure Carrara marble powder with $100 \%$ phosphoric acid. The standard deviation of these measurements was systematically equal to or lower than $\pm 0.15 \%$ o $(1 \sigma)$. The $\mathrm{CO}_{2}$ standard from the Carrara marble used in our laboratory is periodically calibrated against NBS-19. Its isotopic composition is $-2.43 \%$ o ( $\delta^{18} \mathrm{O}$ vs. VPDB $)$ and $+2.45 \%$ o $\left(\delta^{13} \mathrm{C}\right.$ vs. VPDB).

\subsubsection{Strontium isotopes}

Samples were collected from every prominent limestone bed from $10 \mathrm{~m}$ upwards of the composite section and ${ }^{87} \mathrm{Sr} /{ }^{86} \mathrm{Sr}$ isotope analyses were carried out at SUERC (Scottish Universities Environmental Research Centre, East Kilbride, Scotland). Samples were 
leached in $1 \mathrm{M}$ ammonium acetate prior to acid digestion with $\mathrm{HNO}_{3}$. Sr was separated using Eichrom $\mathrm{Sr}$ Spec resin. Matrix elements were eluted in $8 \mathrm{M} \mathrm{HNO}_{3}$ and $3 \mathrm{M} \mathrm{HNO}_{3}$ before elution of $\mathrm{Sr}$ in $0.01 \mathrm{M} \mathrm{HNO}_{3}$. Total procedure blank for $\mathrm{Sr}$ samples prepared using this method was $<200 \mathrm{pg}$. In preparation for mass spectrometry, $\mathrm{Sr}$ samples were loaded onto single Re filaments with a Ta-activator. Sr samples were analyzed with a VG Sector 54-30 multiple collector mass spectrometer. A ${ }^{88} \mathrm{Sr}$ intensity of $1 \mathrm{~V}(1 \times 10-11 \mathrm{~A}) \pm$ $10 \%$ was maintained. ${ }^{87} \mathrm{Sr} /{ }^{86} \mathrm{Sr}$ ratio was corrected for mass fractionation using ${ }^{86} \mathrm{Sr} /{ }^{88} \mathrm{Sr}=0.1194$ and an exponential law. The mass spectrometer was operated in the peak-jumping mode with data collected as 15 blocks of 10 ratios, which gives an internal uncertainty of $<0.000020$ ( $2 \mathrm{~S}$.E.). For this instrument NIST SRM 987 gave $0.710249 \pm 0.000008$ (1 S.D., $\mathrm{n}=17$ ) during the course of this study. The 2 standard error internal precision on individual analyses was between 0.000014 and 0.000020 for $2 \sigma$.

\section{Results}

\subsection{Magnetostratigraphy}

The thermal demagnetization paths show that between the NRM and $180^{\circ} \mathrm{C}$ a normally oriented, low temperature component is generally demagnetized. Between $180^{\circ}$ and $340-560^{\circ} \mathrm{C}$ a second component can be isolated, displaying both normal and reversed polarities and thus interpreted as the characteristic component (ChRM). However, at $340^{\circ} \mathrm{C}$ the specimens collected between 10 and $19 \mathrm{~m}$ still retain $10-20 \%$ of the initial NRM, and a further increase of temperature usually results in randomly oriented direction and/or a rema-

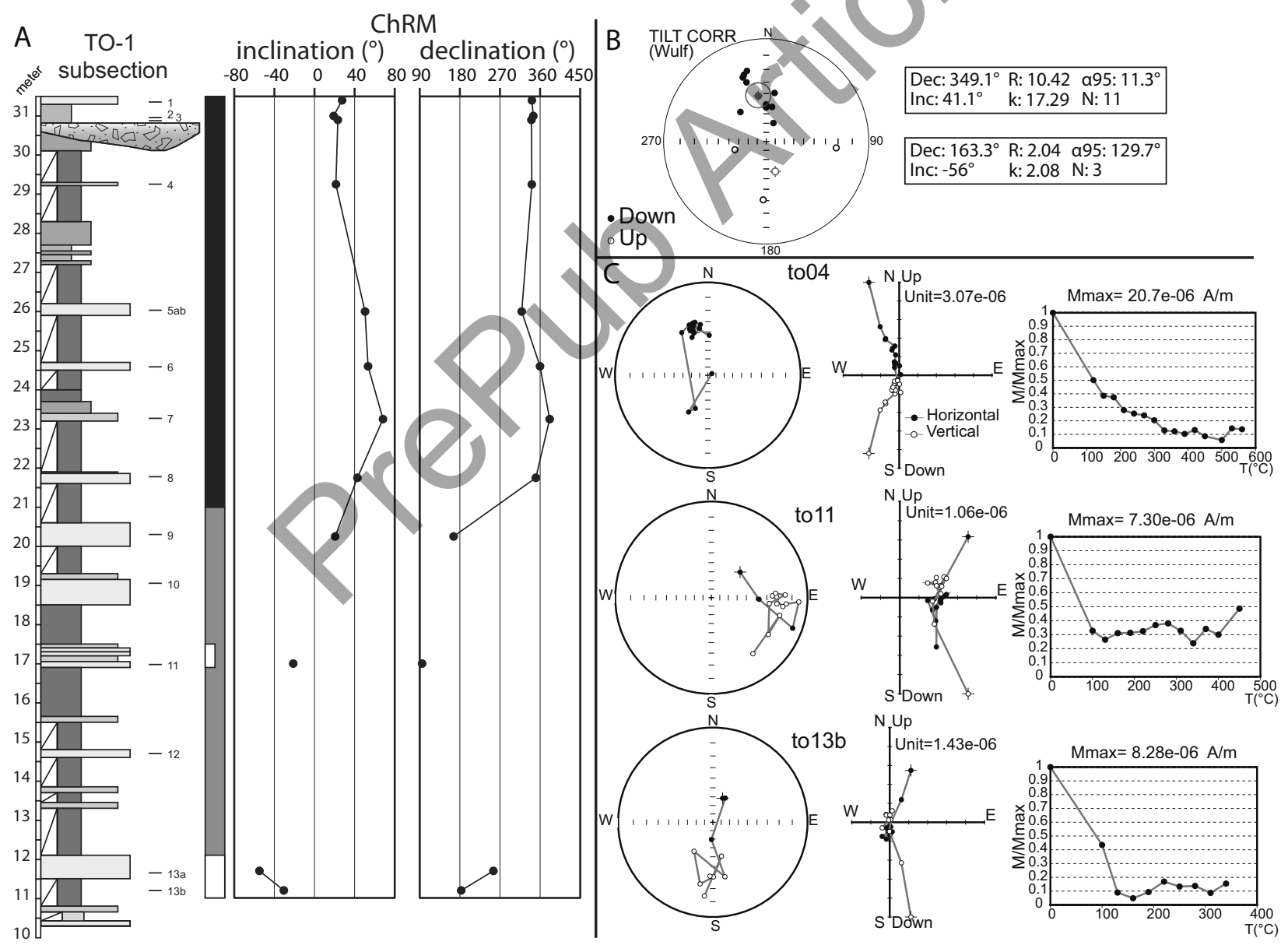

Fig. 3. Magnetostratigraphy of sub-section To-1. A) Plots of the inclination and declination of the characteristic remanent magnetization (ChRM). B) Stereoplot of the tilt corrected ChRM directions; the relative statistical values are reported for the normal and reverse samples in the upper and lower box, respectively. C) Stereoplots, Zijderveld and demagnetization $\left(\mathrm{M} / \mathrm{M}_{\mathrm{max}}\right)$ diagrams relative to the thermal demagnetization paths for three selected samples. 
nence increase. This fact indicates that a potential third component with higher coercitivity also could be present, but not detected in our samples, due to the formation of authigenic magnetic minerals with increasing temperature above $340^{\circ} \mathrm{C}$. In the lower half of the sampled subsection, To13b is the only sample showing a certain reversed ChRM orientation (Fig. 3a, c). Samples To11 and To13a display reversed inclination, but the declination is respectively east and west oriented (Fig. 3b). Samples To12 and To10 were discarded because the signal was too weak. In the upper part of the sampled subsection, the demagnetization paths of samples To01, To05-To08 show the presence of a more stable normal ChRM isolated in a larger temperature range, between $180^{\circ}$ and $460-560^{\circ} \mathrm{C}$ (Fig. 3a). Summarizing, a reversed magnetozone is pinpointed between 11 and $12 \mathrm{~m}$; however, its top is not well defined as sample To11, which tentatively represents the uppermost reversed polarity level, is included in an interval of poorly defined polarities, between 12 and $21 \mathrm{~m}$. A normal magnetozone is identified from 21 and $31.5 \mathrm{~m}$.

\subsection{Planktonic foraminifera}

In sub-unit PK- $\mathrm{A}_{2}$ and in the lower part of sub-unit $\mathrm{PK}-\mathrm{A}_{3}$, up to $7 \mathrm{~m}$ from the base of the composite section (Fig. 2), preservation varies from poor to moderate and deformation and/or incrustation commonly prevents the classification of foraminifera at the species level. Inorganic grains (mainly terrigenous particles and un-disaggregated marly sediment) are often abundant and regardless of the lithology can be prevalent on the fossil remains. Foraminifera are usually more abundant in the marls than in the reddish shales, and planktonic foraminifera are generally more common than the benthic. A common feature is the presence of reworked Eocene to middle Miocene taxa, probably derived from the erosion of the uplifted carbonate formations (Lefkara and Pakhna formations) widespread on the Island of Cyprus (Robertson et al. 1995). In this interval, Globigerinoides spp. and Orbulina universa are generally the most common taxa, among the planktonic foraminifera, followed by neogloboquadrinids (mainly sinistrally coiled), Globigerinita glutinata and Globigerina bulloides.

Semi-quantitative analyses, performed from $7 \mathrm{~m}$ of the composite section upward (Fig.4), indicate that the abundance pattern of foraminifera is characterized by the occurrence of successive peaks, mainly observed in the reddish shales, and that from $11.5 \mathrm{~m}$ up- ward almost all the prominent limestones are devoid of foraminifera (except at $14.6 \mathrm{~m}$, where O.universa occurs). Abundance of planktonic foraminifera first drops above $22 \mathrm{~m}$, where peaks are less prominent and then, just above the conglomerate bed at $31 \mathrm{~m}$, where foraminifera become scattered (Fig.4). As shown by the $\mathrm{P} / \mathrm{B}$ ratio, planktonic are generally much more abundant than benthic foraminifera in the interval from 7 to $15.5 \mathrm{~m}$; upward, the ratio fluctuates with no evident relationship with lithology.

From $7 \mathrm{~m}$ upward, planktonic foraminifer assemblages are more oligotypic with respect to the lower part of sub-unit PK- $\mathrm{A}_{3}$. The genus Turborotalita is rather common, even though discontinuously distributed (Fig.4). T. quinqueloba prevalently occurs in the shales, but it is also present in the thin limestone bed at $10 \mathrm{~m}$ and in the marl at $23 \mathrm{~m}$. It also shows few prominent abundance peaks, reaching up to $100 \mathrm{spec}-$ imens/field in a monospecific assemblage at $10 \mathrm{~m}$ and at $26.5 \mathrm{~m}$. T:multiloba first occurs (FO) at $10.2 \mathrm{~m}$ and is characterized by a very scattered distribution and generally low abundance in the shales, while it is quite common (up to 20-30 specimens/field) only in the limestone layer at $10.2 \mathrm{~m}$ and in a marly level at $23.25 \mathrm{~m}$ (abundance influx, Ai). T.multiloba last occurs (LO) at $31 \mathrm{~m}$, just above the conglomerate (Fig. 4).

The Globigerinita gr. is relatively common between 8 and $21 \mathrm{~m}$ (Fig. 4), attaining abundance maxima at 16 and $21 \mathrm{~m}$; upward, it is very scattered and it disappears above the conglomerate layer at $31 \mathrm{~m}$.

The distribution range of the Globigerina gr. is similar to that of the Globigerinita gr. (Fig.4); however, it is only abundant in the shale at $9 \mathrm{~m}$ and, differently from the latter, it disappears at about $34.5 \mathrm{~m}$, just above the lowermost limestone bed of sub-unit PK-B, i.e. at the stratigraphic level of the last recovery of planktonic foraminifera.

Neogloboquadrina acostaensis is usually rare $(<5$ specimens/field) except at $25.5 \mathrm{~m}$ (35 specimens/ field). The Last regular influx of sinistrally coiled individuals (Lri of Sierro et al. 2001) is recognized at $12.6 \mathrm{~m}$, while at $13.5 \mathrm{~m}$ dextrally and sinistrally coiled specimens occur equally (Fig.4). Dextrally coiled N.acostaensis prevails from $15.25 \mathrm{~m}$ (first abundant occurrence, FAO, of Sierro et al. 2001) and is quite regularly present up to $19.5 \mathrm{~m}$. This taxon is more scattered upwards, vanishing at about $33.5 \mathrm{~m}$, just below the base of sub-unit PK-B (Fig.4).

Globigerinoides spp. are subordinated, showing few minor peaks $(<20$ specimens/field) between 11 and 


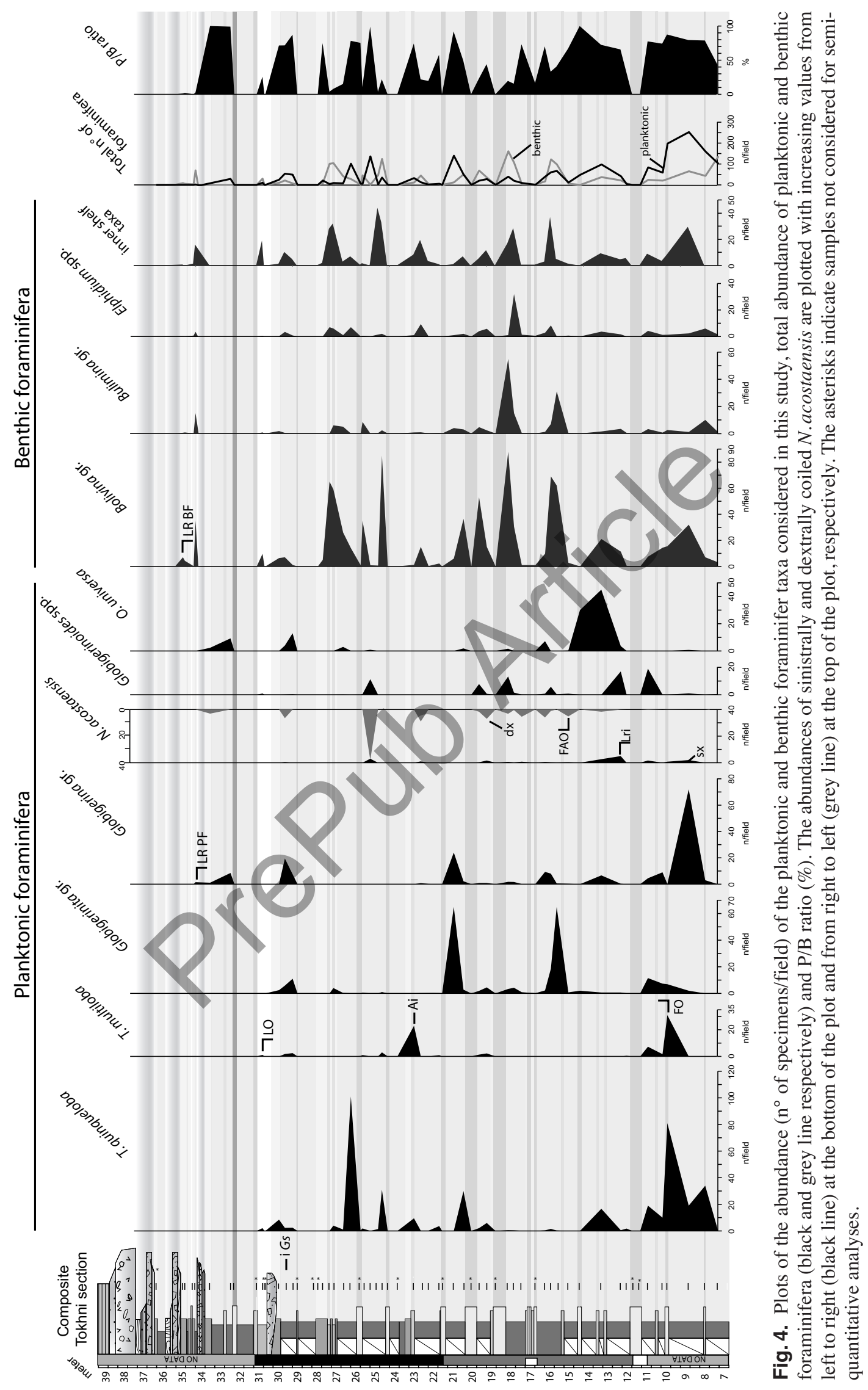


$20 \mathrm{~m}$ and disappear above $25.5 \mathrm{~m}$ (Fig.4). O. universa is irregularly distributed along the composite section and is abundant only between 13 and $14.5 \mathrm{~m}$ (where it is also common in a prominent limestone layer). Globorotalia scitula is present with rare individuals at $29.7 \mathrm{~m}$ (Gs influx in Fig. 4). It is worth observing that the topmost planktonic foraminifer assemblage is represented by O. universa, N.acostaensis and Globigeri$n a \mathrm{gr}$. and the last recovery of planktonic foraminifera (LRp) occurs at $34.5 \mathrm{~m}$.

\subsection{Benthic foraminifera}

In sub-unit PK- $\mathrm{A}_{2}$ and the lower part of sub-unit PK- $\mathrm{A}_{3}$ up to $7 \mathrm{~m}$ of the composite section, the presence of benthic foraminifera is generally subordinate to planktonic ones and mainly represented by Elphidium spp., Neoconorbina orbicularis, Rosalina globularis, Valvulineria complanata, Melonis sp., Gyroidinoides sp., Cibicides spp., Cibicidoides spp., Bolivina gr. (mainly B. spathulata and B.dilatata), Bulimina gr. (mainly B.aculeata, B.echinata and B.elongata), Hanzawaia boueana, Cancris oblungus and Uvigerina bononiensis.
From $9 \mathrm{~m}$ of the Tokhni composite section upward, the benthic assemblages become prevalently dominated by the Bolivina gr. (mainly B. dilatata and B. spathulata), which is particularly abundant in the $15.5-28 \mathrm{~m}$ interval, where it peaks in the shales in correspondence to the P/B minima (Fig.4). Benthic foraminifera are absent in the limestone beds from $11 \mathrm{~m}$ upward, and scattered or absent in some shale levels. A marked abundance decrease is observed from $28.5 \mathrm{~m}$ up to $35.2 \mathrm{~m}$, where the last recovery of benthic foraminifera (LRb), represented by the Bolivina gr., is recorded. In the benthic abundance peaks, the Bolivina gr. is commonly associated with subordinated buliminids, Elphidium spp. and with the inner shelf taxa group (H.boueana, C.oblungus, V.complanata, R.globularis and, rarely, Ammonia sp.). These generally subordinated taxa represent major components of the assemblages just in two samples, at 18 and $25 \mathrm{~m}$ (Fig.4).

\subsection{Calcareous nannofossils}

Calcareous nannofossil assemblages in the upper part of sub-unit PK- $\mathrm{A}_{3}$ and sub-unit PK-B, from $7 \mathrm{~m}$ up to

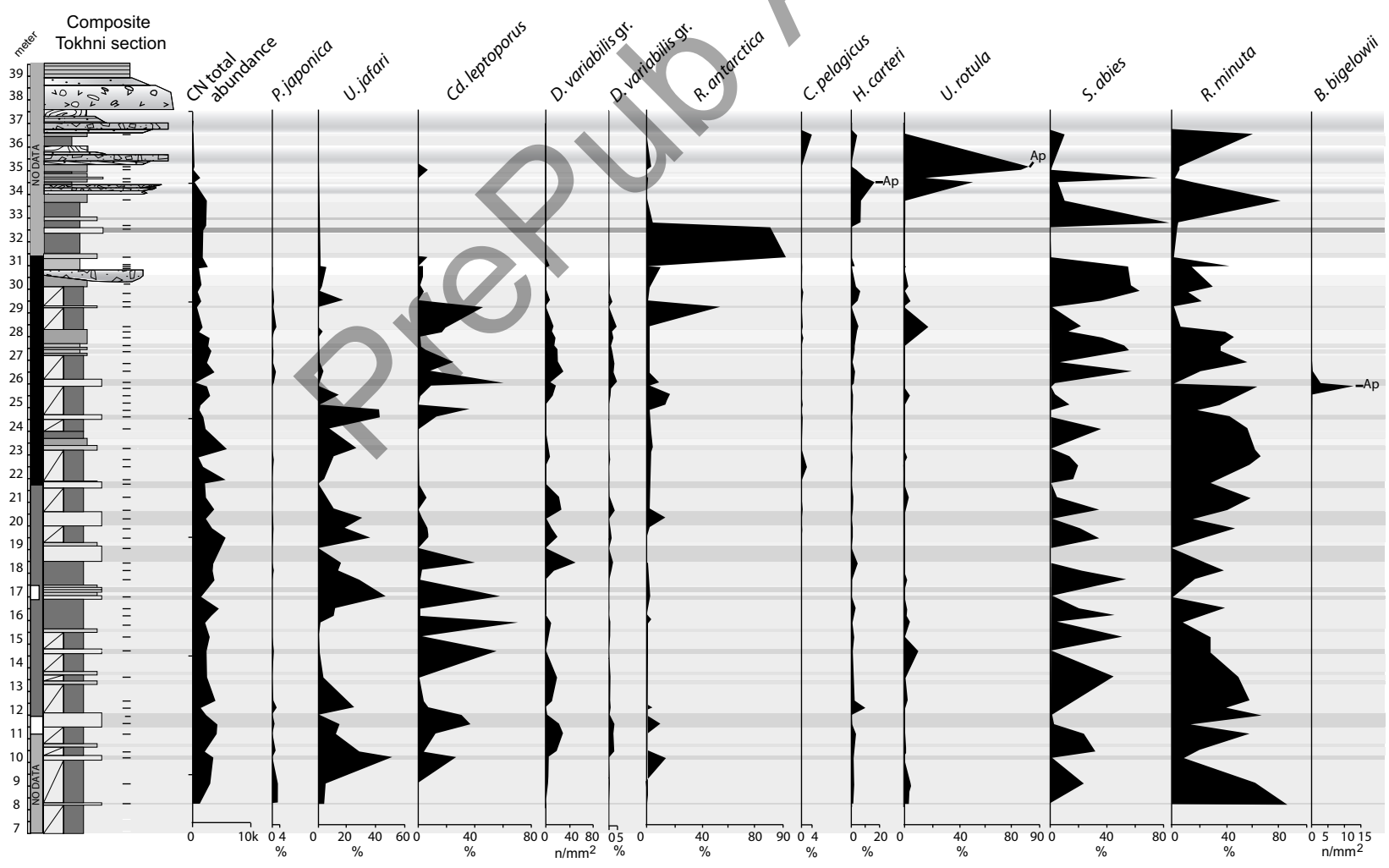

Fig. 5. Plots of the total abundance of calcareous nannofossil $\left(\mathrm{n} / \mathrm{mm}^{2}\right)$ and relative abundances $(\%)$ of the taxa considered in this study. Note that B. bigelowii is only plotted as $\mathrm{n} / \mathrm{mm}^{2}$ and the D. variabilis gr. is plotted as $\mathrm{n} / \mathrm{mm}^{2}$ and $\%$ because of their scattered occurrences along the section. 
the top of the composite section, show moderate to poor preservation. In general, preservation within the micritic limestone layers is poorer than in the shale intervals. Calcareous nannofossils are common to abundant along the section but decrease in abundance at $28.3 \mathrm{~m}$ and at $34 \mathrm{~m}$ (Fig. 5); however they are still present up to the uppermost sample at $36.5 \mathrm{~m}$. Reworking of calcareous nannofossils from sediments as old as Early Cretaceous occurs sporadically and mainly in the reddish shales of each cycle. Nonetheless, abundance of reworked specimens is very low and does not hinder the quantitative analysis of the assemblages. Diatoms were also detected in the smear slides prepared for calcareous nannofossil analyses and occur, with discontinuous abundances, from $12.2 \mathrm{~m}$ upward; remarkably, limestones were devoid of diatoms (R. Jordan, pers. comm. 2014).

Major component of the fossil assemblages along the entire section are reticulofenestrids (Reticulofenestra minuta, R.haqii, R.pseudoumbilicus, which represent up to $80 \%$ of the total assemblage), together with Sphenolithus abies (up to 80\%), Calcidiscus leptoporus (up to $70 \%$ ) and Umbilicosphaera jafari (up to $45 \%$ ) (Fig.5). R.minuta is present in both the limestones and in the middle/upper part of the shales; however, in the latter it retains the abundance maxima. Differently, S.abies is virtually absent in the limestones and generally shows greater abundance in the lower part of the shales. The greater abundance of Cd.leptoporus occurs in the limestone layers up to $29.25 \mathrm{~m}$; above this level its abundance drops to less than $5 \%$ and it is replaced by Reticulofenestra antarctica within the limestones up to $32.5 \mathrm{~m}$. U.jafari is prevalently present with abundance peaks in the limestones up to $31 \mathrm{~m}$, where it disappears.

U.rotula is a minor component (with peak close to $18 \%$ ) of the assemblage up to $34 \mathrm{~m}$, but it reaches $90 \%$ in the abundance peak (Ap) between limestones $\mathrm{A}$ and $\mathrm{B}$ of PK-B sub-unit $(35 \mathrm{~m})$ (Fig. 5). Helicosphaera carteri shows low abundances up to $26 \mathrm{~m}$, reaching $15 \%$ of the total assemblage at $34.5 \mathrm{~m}$. Discoaster spp. occurs from the bottom of the section and the Discoaster variabilis gr. $(<5 \%)$ is quite regularly present in three intervals: $10-12 \mathrm{~m}, 18-21 \mathrm{~m}$ and 25.5-29.5 m. It is prevalent in the shales, but it also occurs in the lower part of the limestones at $11.5 \mathrm{~m}$ and at $26 \mathrm{~m}$. Braarudosphaera bigelowii shows an abundance peak $\left(130 \mathrm{n} / \mathrm{mm}^{2}\right)$ at $25.8 \mathrm{~m}$ (Fig. 5), being otherwise absent below and above this layer.
The biostratigraphically useful taxa Amaurolithus delicatus and A.primus are generally very rare and shows very scattered occurrences.

\subsection{Isotopic geochemistry $\left(\delta^{18} \mathrm{O}, \delta^{13} \mathrm{C}\right.$ and ${ }^{87} \mathrm{Sr} /{ }^{86} \mathrm{Sr}$ )}

Oxygen isotope values (Fig. 6) range from $-4.57 \%$ o to $2.49 \%$ (PDB), showing a cyclic stacking pattern with heavier values in the limestones and lighter values in the reddish shales and pink diatomites. The heaviest values are observed in the limestones below $9 \mathrm{~m}$; a shift towards more depleted values is recorded between 9 and $18.5 \mathrm{~m}$, both in the limestones and in the shales. From 18.5 up to $34 \mathrm{~m}$ (base of sub-unit PK-B) positive and negative values of $\delta^{18} \mathrm{O}$ quite regularly match with the limestones and shales, respectively; however, relative maxima close to zero are documented between 26.5 and $28.5 \mathrm{~m}$. At $34 \mathrm{~m}$ a sudden drop towards the most negative values of the succession is observed; minima occur in the grey and pink shales, while the uppermost three carbonates show values close to zero. Carbon isotope values are prevalently negative, ranging from $-3.19 \%$ o to $-0.5 \%$ (PDB), without any evident relationship with lithology (Fig. 6). Just one positive peak at $0.51 \%$ was measured in the lowermost limestone of the sub-unit PK-B. However, a covariance is observed in the long-term trends between the oxygen and the carbon curves: an increase from the bottom to $4.5 \mathrm{~m}$ is followed by an overall decrease down to a minimum at $16 \mathrm{~m}$. Upward an increasing trend is recorded up to $22 \mathrm{~m}$, where a relative maximum of $-0.74 \%$ occurs. Further up, values range between -2 to $-1 \%$ and are punctuated by a positive peak corresponding to the laminated portion of the lowermost carbonate of subunit PK-B. As the lowermost carbonate of sub-unit PK-B is laminated, we measured the isotope ratios for two white and brown consecutive laminas. Remarkably, the isotopic signatures of these two laminae are different, as we obtained $\delta^{18} \mathrm{O}$ and $\delta^{13} \mathrm{C}$ values of $-1.31 \%$ and $-0.58 \%$ or the white and of $0.17 \%$ and $0.51 \%$ for the brown lamina, respectively.

The ${ }^{87} \mathrm{Sr} /{ }^{86} \mathrm{Sr}$ isotopic ratio is generally slightly greater than that of the oceanic mean values (Mc Arthur et al. 2001) in sub-unit PK-A 3 (Fig.6), except for samples at 20.25, 24.5 and $32.5 \mathrm{~m}$. Conversely, in sub-unit PK-B the isotopic ratio gradually decreases below the oceanic values, showing two minima in the clastic limestones B and C. 


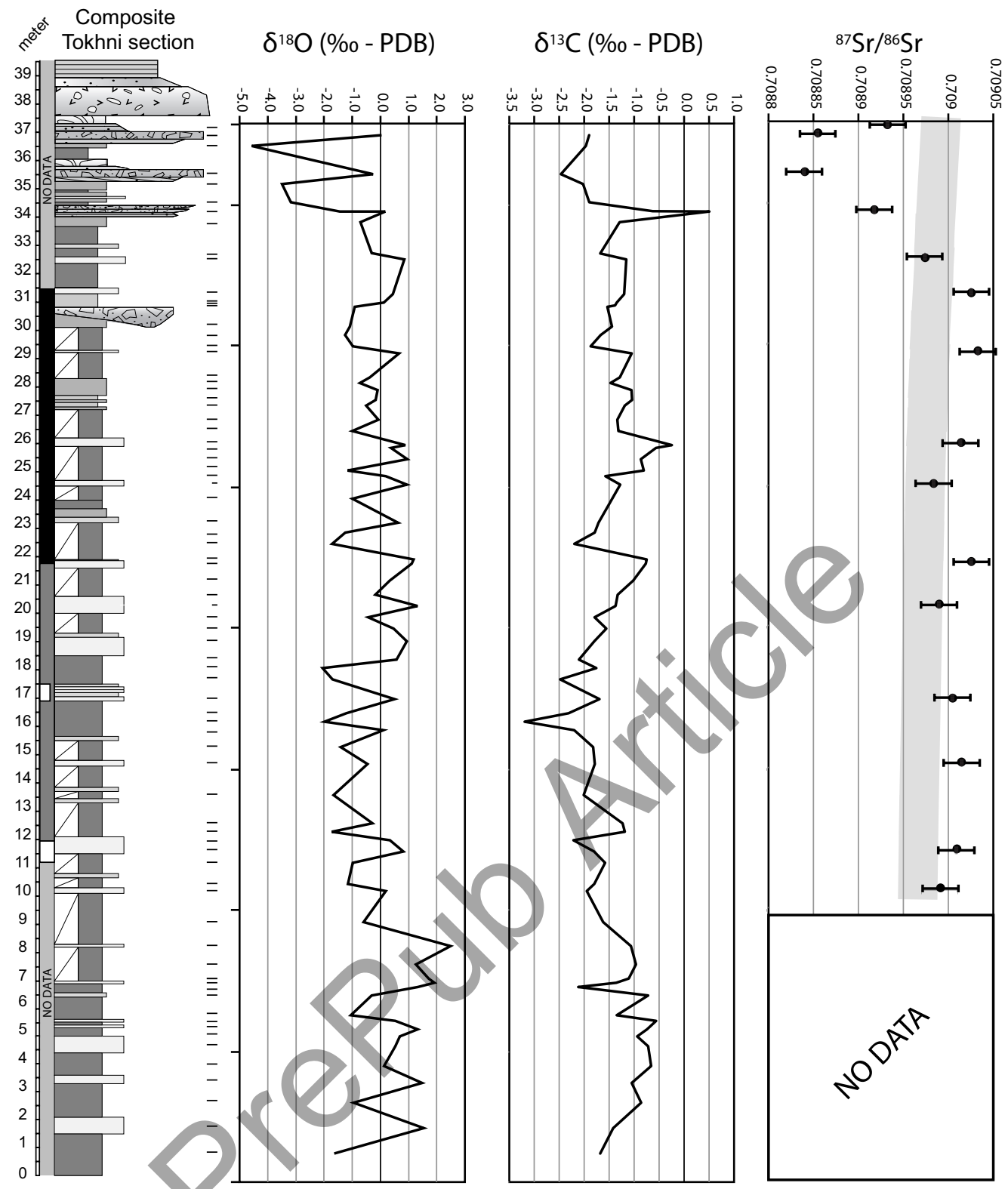

Fig. 6. Plots of the bulk oxygen and carbon isotopic values (both measured in shales and limestones) and of the bulk Sr isotopic ratio (only measured in limestones) of the Tokhni composite section.

\section{Discussion}

\subsection{Biomagnetostratigraphy}

In terms of planktonic foraminiferal biostratigraphy, the FO of T.multiloba (dated at 6.415 Ma in the Perales section by Sierro et al. 2001) at $10.2 \mathrm{~m}$, the Lri of N.acostaensis with predominant sinistral coiling (6.378 Ma; Sierro et al. 2001) at $12.6 \mathrm{~m}$, the FAO of dextrally coiled N.acostaensis (6.339 Ma; Sierro et al.
2001) at $15.25 \mathrm{~m}$ allow us to assign the middle and upper part of PK- $\mathrm{A}_{3}$ sub-unit to the Messinian biozones MMi 13b and MMi 13c of Iaccarino et al. (2007). The MMi 13b/MMi 13c subzonal boundary is defined by the coiling change of $N$.acostaensis between 12.6 and $15.25 \mathrm{~m}$. The succession of these events also indicates that discontinuous reversed polarity samples recorded between 11 and $12 \mathrm{~m}$ and at $17 \mathrm{~m}$ are referable to the C3An.1r sub-chron (Sierro et al. 2001). In the upper part of the composite section, the influx of G.scitula 
(29.7 $\mathrm{m}$ ) and the LO of T. multiloba (31 m) occur within a normal polarity magnetozone. The same succession of events is observed in the Perales section, where they occur within sub-chron C3An.1n and are respectively dated at 6.102 and 6.04 Ma (Sierro et al. 2001). Thus, the influx of G. scitula at $29.7 \mathrm{~m}$ can be correlated to its $2^{\text {nd }}$ influx recognized in the Perales section (Sierro et al. 2001) and the normal magnetozone between 22 and $31.5 \mathrm{~m}$ is correlated to sub-chron C3An.1n. The LR of planktonic and benthic foraminifera between limestones $\mathrm{A}$ and $\mathrm{B}$ in the sub-unit PK-B marks the base of the Non-Distinctive Zone (NDZ) of Iaccarino et al. (2007) and are considered as a good approximation of the MSC onset. In fact, the LR of planktonic (LRp) and benthic $(\mathrm{LRb})$ foraminifera $(>125 \mu \mathrm{m})$ have been recognized in the penultimate cycle (Perales, Falconara, Legnagnone) and in the last cycle of the pre-MSC unit (Perales, Legnagnone), respectively (Blanc-Valleron et al. 2002, Gennari et al. 2013, Manzi et al. 2011, 2013, Sierro et al. 2003). In the Pollenzo section the LRp and the $\mathrm{LRb}(>125 \mu \mathrm{m})$ have been recognized in the $1^{\text {st }}$ and $2^{\text {nd }}$ PLG cycles, respectively (Violanti et al. 2013), but a strong decrease in the foraminifer abundance marks the onset of the MSC.

Regarding calcareous nannofossils, the occurrence of A.delicatus and A.primus from the bottom of the composite section, albeit scattered, indicates the presence of the MNN11b/c biozones (Raffi et al. 2003). In addition, recently, calcareous nannofossil bioevents have been identified associated with the onset of the MSC in the Northern Apennine (Manzi et al. 2007, Dela Pierre et al. 2011, Violanti et al. 2013). For instance, a sharp abundance peak of S.abies, associated with abundant $H$.carteri and shortly followed by an abundance peak of $U$ rotula close to $60 \%$ of the assemblage, is reported in the Pollenzo section (NW Italy) in the sediments deposited during the first Primary Lower Gypsum (PLG) cycle (Lozar et al. 2010 and this volume, Violanti et al. 2013). Remarkably, both at Pollenzo and in the Fanantello borehole (Northern Apennine, Italy; Manzi et al. 2007), S.abies shows low abundances all over the section, with a noticeable $60 \%$ abundance peak at the base of the first PLG equivalent cycle. In the Tokhni section, on the contrary, this S.abies peak is not unambiguously detectable since this taxon is abundant and regularly occurs in all the shales. However, the sharp increase in abundance of both H.carteri and U.rotula at 34.5 and $35 \mathrm{~m}$ respectively, close to the LR of planktonic and benthic foraminifera, shows their reliability to approximate the onset of the MSC.

\subsection{Cyclostratigraphy}

The Tokhni section presents a well-defined cyclic lithologic stacking pattern. The cycles of sub-unit PK$\mathrm{A}_{3}$ are generally made up of reddish shales and prominent whitish limestones. However, while the shaley hemicycle is a constant feature of the sedimentary cycles along all the composite section, limestones can be associated with or replaced by marls and/or pink diatomites. In the sub-unit PK-B the recognition of sedimentary cycles is complicated by the clastic nature of the limestones A (upper part), B and C. This suggests that they should not be considered equivalent to the limestones of the sub-unit PK-A 3 (see Manzi et al. 2016). On the whole, in the Tokhni composite section from $7 \mathrm{~m}$ up to the base of the gypsum deposits, we identified 25 cycles (Fig.7); the thickness of these cycles is rather variable and ranges from $0.5 \mathrm{~m}$ (cycle 21) up to $2 \mathrm{~m}$ (e.g., cycles 2 and 8 ). The occurrence of 16 cycles in a time interval of $340 \mathrm{kyr}$ (between the FO of T. multiloba and the $2^{\text {nd }}$ influx of G. scitula) implies an average duration of $21 \mathrm{kyr}$ for each cycle, suggesting a relationship with precession, as previously observed by Orszag-Sperber et al. (2009). Because of the absence of sapropels and the scarcity of diatomites, the sedimentary cycles at Tokhni are more similar to those of the Pissouri section, described as an alternation of carbonates (insolation minima) and marls (insolation maxima) (Krijgsman et al. 2002), than to other preMSC cycles. In particular, they differ from a) the tripartite cycles of the Falconara and Gavdos sections (Blanc-Valleron et al. 2002, Pérez-Folgado et al. 2003), where sapropels and marls intercalated by diatomites are tied to insolation maxima and minima, respectively; b) the quadripartite cycles of Sorbas basin, where the sapropel is correlated to insolation maxima and followed by lower marl, diatomite and upper marl (insolation minima) (Sierro et al. 2001, 2003).

The cyclicity at Tokhni is also emphasized by fluctuations of the oxygen isotope values and of the abundance of several calcareous nannofossil taxa. In fact, heavier $\delta^{18} \mathrm{O}$ values are associated with limestones and marls, indicating more arid and/or colder conditions, while lighter values are recorded in shales and diatomites, pointing to more humid and/or warmer conditions (Fig. 6). These oscillations were also observed in the bulk sample stable isotope record of Falconara section (Blanc-Valleron et al. 2002), where the heavier and lighter values, respectively, correspond to marls/ diatomites (insolation minima) and to sapropels (insolation maxima) (see also Hilgen and Krijgsman 1999). 
Regarding calcareous nannofossils, shales are characterized by the occurrence of S.abies, and R.minuta, (dominant in the lower/middle and upper part of the layer, respectively), both sporadically associated with less abundant D.variabilis gr $(<5 \%)$. This assemblage is strikingly similar to that observed in the sapropels of the Sorbas basin (Flores et al. 2005). Thus, the calcareous nannofossil assemblages and the lighter $\delta^{18} \mathrm{O}$ values suggest the correlation between the reddish shales of the Tokhni composite section and insolation maxima (Fig. 7).
Cd.leptoporus and $U$.jafari are the main components of the calcareous nannofossil assemblage in the limestones and marls up to $29.5 \mathrm{~m}$ and their co-occurrence was also observed in the upper marls of the Sorbas basin, correlated with insolation minima (Sierro et al. 2003, Flores et al. 2005). Thus, the occurrence of these two taxa and the heavier $\delta^{18} \mathrm{O}$ suggest the correlation between the limestones of the Tokhni composite section and insolation minima.

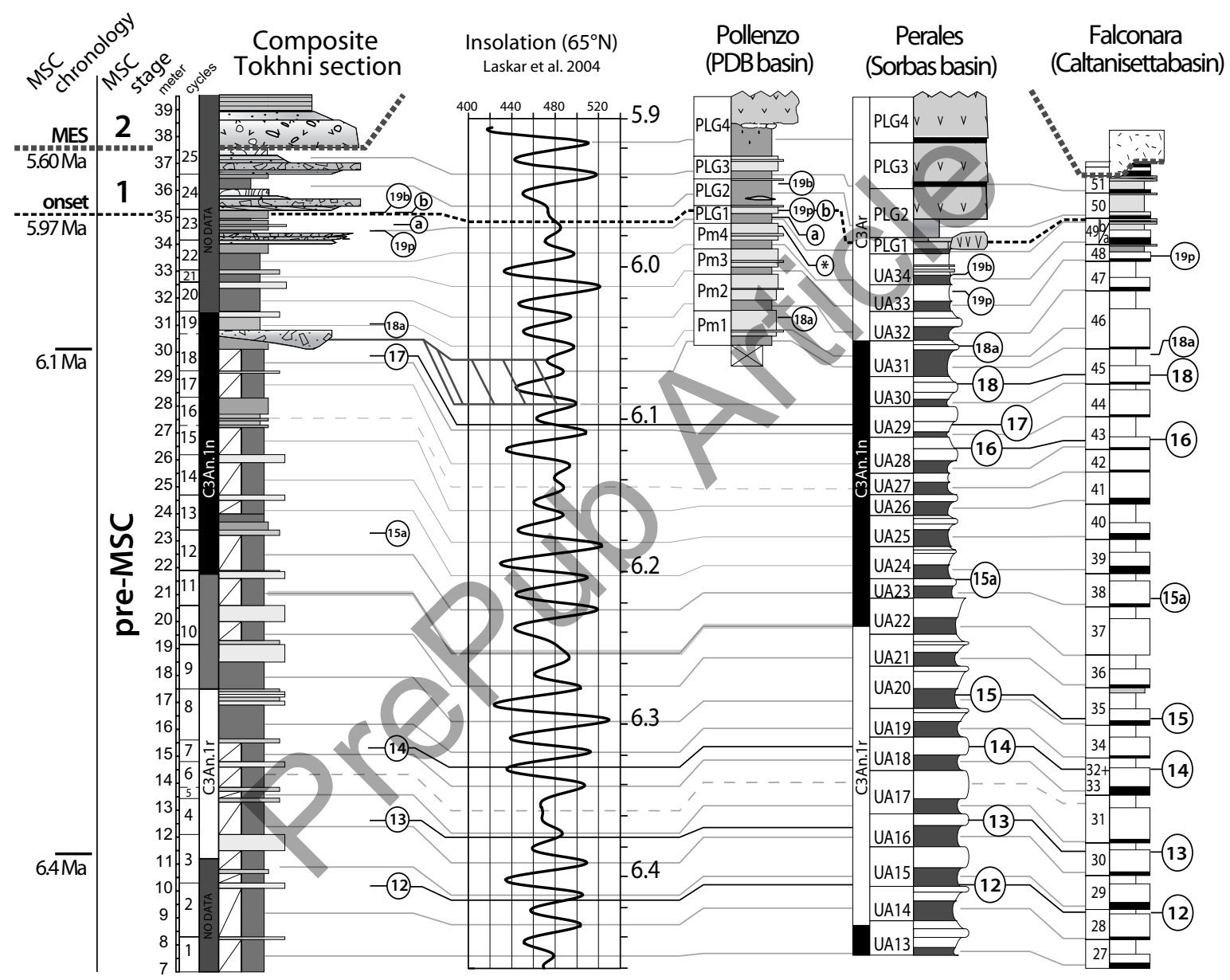

Fig. 7. Biomagnetostratigraphic and cyclostratigraphic correlation of the Tokhni composite section to the Pollenzo (Lozar et al. 2010, Violanti et al. 2013), Perales (modified after Sierro et al. 2001 and Manzi et al. 2013) and Falconara (modified after Hilgen and Krijgsman 1999, Blanc-Valleron et al. 2002 and Manzi et al. 2011) sections. The successions are tuned to the $65^{\circ} \mathrm{N}$ summer insolation curve (Laskar et al. 2004). Planktonic foraminifer events are indicated by numbers following the codification of Sierro et al. (2001) (a letter is added for new bioevents): 12) first occurrence (FO) of T.multiloba; 13) Last regular influx (Lri) of $N$. acostaensis sinistral coiling; 14) first abundant occurrence (FAO) of $N$.acostaensis dextral coiling; 15) $1^{\text {st }}$ influx of G. scitula; 15a) abundance influx of T.multiloba; 16) $1^{\text {st }}$ influx of $N$.acostaensis sinistral coiling; 17) $2^{\text {nd }}$ influx of G. scitula; 18) $2^{\text {nd }}$ influx of N.acostaensis sinistral coiling; 18a) last occurrence (LO) of T. multiloba; 19p) last recovery (LR) of planktonic foraminifera; 19b) last recovery (LR) of benthic foraminifera. Calcareous nannofossil events (Violanti et al. 2013): a) H.carteri peak; b) U.rotula peak. On the left side of the figure, the boundaries between the pre-MSC stage, stage 1 and 2 of Roveri et al. (2009) and the MSC chronology are indicated. Note that a hiatus of ca. $350 \mathrm{kyr}$ is present between stage 1 and 2 due to the erosion associated with the Messinian erosional surface (MES). 


\subsection{Age model}

To reconstruct the age model for the Tokhni composite section, the calcareous plankton events have been used as tie points and the sedimentary cycles have been correlated to the $65^{\circ} \mathrm{N}$ summer insolation curve (Laskar et al. 2004), on the basis of the phase relation above exposed (Fig.7). The resulting age model has been compared with the astronomically calibrated Messinian reference sections of Pollenzo, Perales and Falconara (Fig. 7).

The astronomical calibration of the Tokni composite section shows a good fit with the 100 kyr ecentricity cycles, reflected in the intervals of low and high amplitude variations of the summer insolation curve, corresponding to eccentricity minima and eccentricity maxima, respectively. In particular, the thick limestone of cycle 3 corresponds to the high amplitude insolation cycle at ca. $6.4 \mathrm{Ma}$; the thick cycles 8,9 and 10 well correlate with the cluster of high amplitude insolation cycles centred at $6.3 \mathrm{Ma}$; the prominent limestones of cycle 13 and 14 well fit with the high amplitude insolation cycle at $6.2 \mathrm{Ma}$. Indeed, eccentricity minima $(6.36,6.14,5.97 \mathrm{Ma})$ can be identified in the sedimentary record for the absence of prominent limestones, replaced by thin marls or pink diatomites (cycles 5, 15-16 and 23; Fig. 7). Moreover, the oxygen isotope curve also displays overall lighter values and smoother oscillations in both the 6.36 and $6.14 \mathrm{Ma}$ eccentricity minima. The sedimentary response to the $100 \mathrm{kyr}$ eccentricity cycle is a good constraint for the proposed age model; however, an additional tie point could be represented by the influx of T.multiloba in the 15$29.5 \mathrm{~m}$ interval, where the C3An.1r/C3An.1n reversal is poorly constrained and standard bioevents are lacking (Fig. 7). This bioevent occurs at the base of the sub-chron C3An.1n, five precessional cycles above the FAO of dextrally coiled N.acostaensis and six cycles below the $2^{\text {nd }}$ influx of G. scitula. In the same stratigraphic position, in the Perales and Falconara successions (Sierro et al. 2001, Blanc-Valleron et al. 2002) T.multiloba shows a very prominent influx (up to $100 \%$ of the assemblage), which marks a paracme end dated at $6.21 \mathrm{Ma}$, based on its occurrence in the upper part of cycle UA23 of Sierro et al. (2001).

In the upper part of the composite section, the relative position of the LO of T.multiloba with respect to the $2^{\text {nd }}$ influx of G. scitula (within sub-chron C3An.1n) indicates that an erosion of ca. 2 sedimentary cycles is associated with the base of the conglomerate at $30.5 \mathrm{~m}$ (Fig.7). In fact, at Tokhni, these events are recorded in two consecutive sedimentary cycles, i.e. below and above the conglomerate, while in the Perales section they are separated by three insolation minima (Sierro et al. 2001).

The proposed age model indicates that the onset of the MSC at 5.971 Ma (Manzi et al. 2013) occurs between the two lowermost limestones of the sub-unit PK-B (Manzi et al. 2016), ca. 4 precessional cycles above the LO of T.multiloba and well approximated by the LR of benthic and planktonic foraminifera and by the abundance peaks of U.rotula and H.carteri. In this interval the sedimentary cyclicity is poorly defined by the thin alternation of shales and diatomites due to the concomitant eccentricity minima.

Moreover, the identification of the MSC onset at ca. one precessional cycle below the MES (5.60 Ma, Krijgsman et al. 1999a) implies a hiatus of ca. $350 \mathrm{kyr}$, due to the erosion of most of the sediments associated with Stage 1 of the MSC.

\subsection{Paleoenvironmental reconstruction}

\subsubsection{Interval 1: pre 6.4 Ma}

In the lower part of the section, prior to $6.4 \mathrm{Ma}$, benthic foraminifer assemblages are similar to those recorded in the 7.16-6.4 Ma interval of the Pissouri section (Kouwenhoven et al. 2006). They include genera typically representative of inner shelf to upper bathyal habitats (Murray 2006). The presence of inner shelf genera, such as Elphidium, Neoconorbina, Rosalina and Ammonia, as well as of reworked planktonic foraminifera, is interpreted as due to downslope transport, a process commonly observed in the pre-MSC successions of Crete and Cyprus (Van der Zwaan 1982, Kouwenhoven et al. 2006). Thus, the diversified benthic foraminifer assemblages and the common occurrence of ostracods indicate an upper bathyal paleoenvironment and the prevalence of an oxygenated sea floor (Boomer and Eisenhauer 2002). Still, the relative high abundances of the Bolivina and Bulimina groups at some levels point to episodes of enhanced nutrient availability and lower oxygen levels (Jorissen 1987, Kahio 1994). The prevalence of Globigerinoides spp. and O.universa in the planktonic assemblages of the basal portion of the Tokhni composite section suggests overall warm and oligotrophic conditions in the upper water column (Fig.8). The occurrence of T.quinqueloba, T. multiloba and of G. bulloides from cycle 2 (6.44 Ma) upwards documents the establishment of more eutrophic conditions (Sierro et al. 2003). 


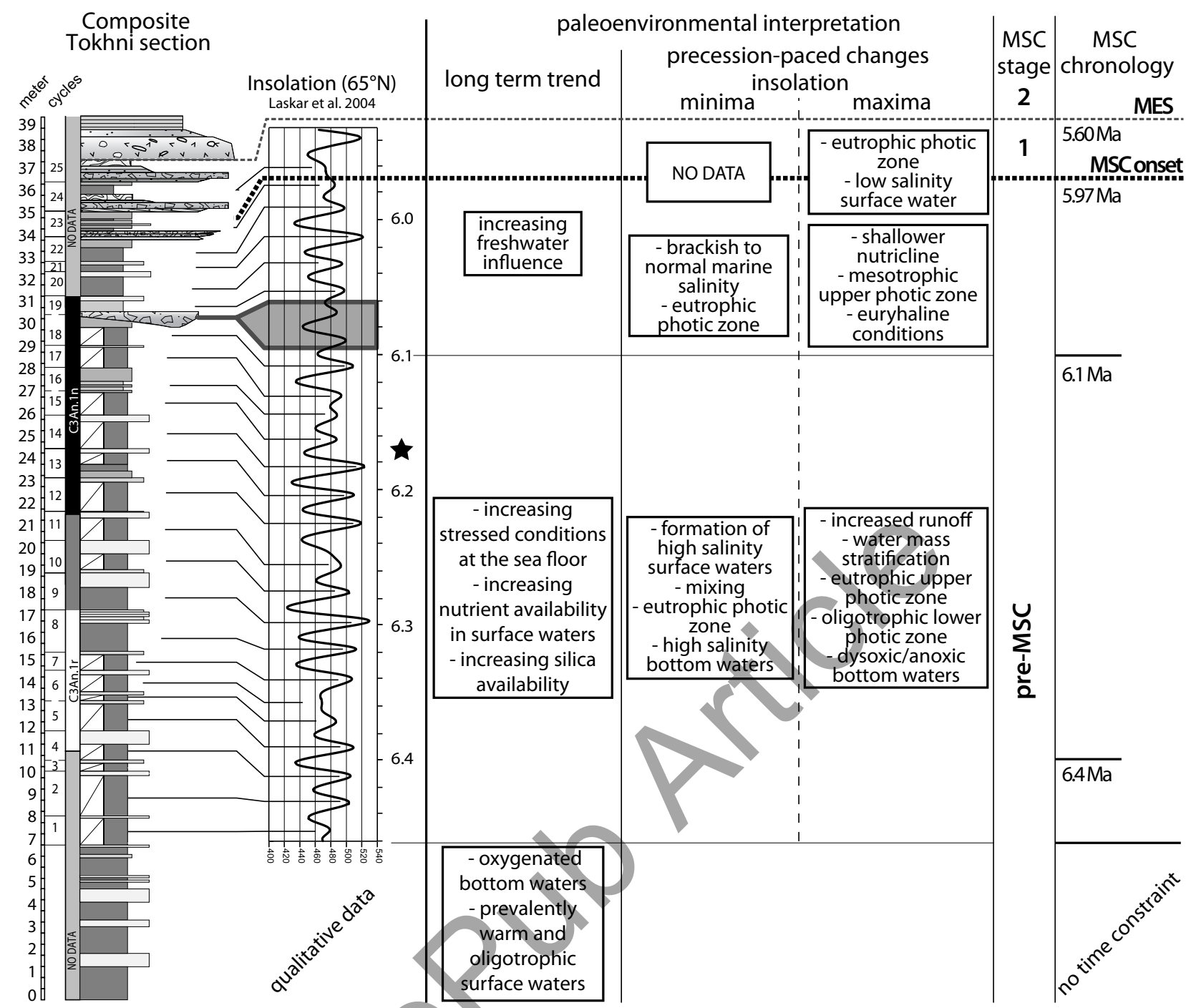

Fig. 8. Summary of the paleoenvironmental changes recognized in the Tokhni composite section. The paleoenvironmental interpretation of the chronologically unconstrained lowermost $11 \mathrm{~m}$ of the section relies upon qualitative observations on foraminifera. The black star beside the insolation curve indicates the position of the influx of B. bigelowii, suggesting a transient connection with the paleo-Black sea. On the right side of the figure, the boundaries between the pre-MSC stage, stage 1 and 2 of Roveri et al. (2009) and the MSC chronology are indicated. Note that a hiatus of ca. 350 kyr is present between stage 1 and 2 due to the erosion associated with the Messinian erosional surface (MES).

\subsubsection{Interval 2: 6.4-6.1 Ma}

From $6.4 \mathrm{Ma}$, the shales are characterized by the dominance of the opportunistic Bolivina (mainly B.spathulata and B.dilatata) and, subordinately, Bulimina groups (mainly B.echinata and B.aculeata). These species co-occur with inner shelf benthic foraminifera and with abundant sponge spicules (Fig.8), both considered the result of downslope transport. The autochthonous fauna indicates bottom waters characterized by high organic matter supply, low oxygen levels and, according to Kouwenhoven et al. (2006), also by increased salinity. The disappearance of ostracods also points to substantial oxygen decrease at the sea bottom, whereas the abundance of sponge spicules either reveals increased availability or optimal preservation of silica. These changes occurred synchronously in the adjacent Pissouri basin and we infer that they are related to the establishment of stressed condition at the sea floor (Kouwenhoven et al.2006), rather than a shallowing upward trend (see also Orszag-Sperber et al. 2009).

This interval is usually characterized in the Mediterranean by increased oscillations of the $\mathrm{P} / \mathrm{B}$ ratio $(0-$ 
$100 \%$ ) indicating the establishment of precessionpaced anoxic bottom water conditions (insolation maxima) and stressed surface waters (hypertrophic/high salinity) during insolation minima (Blanc-Valleron et al. 2002, Sierro et al. 2003, Kouwenhoven et al. 2006). At Tokhni, as well, we observe an increased response to the insolation index, which involves marked micropaleontologic differences between the shales (insolation maxima) and the limestones (insolation minima). However, a clear relation between assemblage composition and lithology is only shown by calcareous nannofossils, as foraminifera are generally only present in the shales and do not show a regular distribution pattern.

The shaley hemicycles record the association of the aforementioned opportunistic benthic foraminifera with S.abies, D.variabilis gr., R.minuta and with lighter $\delta^{18} \mathrm{O}$ values. In the Atlantic Ocean Pliocene record and in the Messinian sapropels of the Sorbas basin, Discoaster spp. and S.abies positively respond to low nutrient availability in the lower photic zone (LPZ) and to warm sea surface temperatures (Gibbs et al. 2004a, Flores et al. 2005). R.minuta is an opportunistic taxon tolerating wide ecological changes and blooming in nutrient-rich surface waters (Aubry 1992, Flores et al. 1995); in particular, the increase of small sized Reticulofenestra has been correlated with increased riverine input in the Caribbean Pliocene record (Kameo 2002) and, associated with a decrease of Discoaster, has been related to meso- to eutrophic condition in the Late Miocene Pacific record (Imai et al. 2015). In the lower/middle part of the Tokhni shales the occurrence of R.minuta associated with dominant S.abies and rare specimens of the D. variabilis gr. suggests that at times of insolation maxima R.minuta could thrive in the upper photic zone, where high nutrient levels were mainly provided through increased continental runoff, which also favoured the stratification of the water column. More oligotrophic condition prevailed in the LPZ favouring the proliferation of $S$.abies and, to a minor extent, of $D$. variabilis gr. In the upper part of the shales, R.minuta becomes dominant (40-60\%), generally following a drop in abundance of S. abies. Similar to the Sorbas basin (Flores et al. 2005), this could indicate increasing nutrient availability in the surface layer immediately after the insolation maxima, when the transition to a more arid condition, typically established during insolation minima, favoured the onset of deep/intermediate water ventilation.

Therefore, by analogy with the formation of the Late Miocene and Plio-Pleistocene sapropels (Nijen- huis et al. 1996), we argue that continental runoff increased during insolation maxima, triggering the stratification of the water column and raising nutrient and silica levels. The oxygen consumption at the sea floor was favoured by the elevated organic matter levels supplied directly from the continent and from the primary productivity in the photic zone (Fig. 8). The combination of these processes favoured the formation of dysoxic or anoxic bottom waters, as indicated by abundance peaks of the Bolivina and Bulimina groups and levels with scarce or no benthic foraminifera. Differently, benthic foraminifera are completely absent in sapropels deposited after 6.4 Ma in the Western Mediterranean Perales section, indicating the establishment of prolonged permanent sea floor anoxia in response to a stronger density stratification of the water column at times of insolation maxima (Sierro et al. 2003).

In the marls and limestones of this interval Cd.leptoporus occurs with U.jafari, while, remarkably, foraminifera are generally absent. The possibility that dissolution had altered the micropaleontologic record of the limestones is regarded as unlikely, since the co-occurrence of the very resistant Cd.leptoporus (McIntyre and McIntyre 1971, Dittert et al. 1999, Ziveri et al. 2007) with the very delicate $U$.jafari (Gibbs et al. $2004 \mathrm{~b}$ ), recorded in abundances higher than $30 \%$, is taken as indication of minor diagenetic effects on the assemblage.

Extant $C$ d.leptoporus has broad ecological preferences and opportunistic behaviour (Renaud et al. 2002, Boeckel et al. 2006, Baumann et al. 2016). In fact, it is related to warm/temperate waters with higher nutrient input to the upper photic zone and a shallower nutricline, possibly driven by effective mixing due to upwelling (Ziveri et al. 2004, Ausin et al. 2015). Cd.leptoporus is abundant and associated with small placoliths (i.e. small reticulofenestrids) in the basal homogeneous marls of each cycle of the pre-MSC Serra Pirciata and Torrente Vaccarizzo sections (Caltanissetta Basin, Sicily; Bellanca et al. 2002), where it co-occurs with T.quinqueloba and N.acostaensis, indicating cooler and eutrophic waters. At Sorbas, U.jafari can be abundant in the upper marls (insolation minima) and is inferred to tolerate high salinity (Flores et al. 2005).

The presence of these taxa together with the heavier $\delta^{18} \mathrm{O}$ values suggest that during insolation minima the higher evaporation rate increased the sea surface salinity, favouring the mixing of the water mass, the formation of deep/intermediate waters and triggering eutrophic conditions in the upper part of the water column. 
This mechanism is similar to that allowing the formation of the Levantine Intermediate (and Deep) Water, which, at present, originates in winter in the CyprusRhodes Area and resides between 150 and $600 \mathrm{~m}$ in the eastern Mediterranean (Rohling et al. 2015). Notably, the absence of $U$.jafari and the lighter $\delta^{18} \mathrm{O}$ in the intervals correlated to eccentricity minima (cycles $6-7$, 11 and 15-17) could indicate that the lowered seasonality decreased the formation rate of highly saline superficial waters. Note, however, that the relatively lighter $\delta^{18} \mathrm{O}$ maxima measured in the limestones of these intervals may be also related to the abundance of Cd.leptoporus in these layers, as this species is known to calcify at negative disequilibrium with the ambient sea water (Dudley and Nelson 1989, Ziveri et al. 2003, Hermoso et al. 2014).

The absence of benthic and planktonic foraminifera in almost all limestones of this interval represents a peculiarity of the Tokhni section with respect to the Mediterranean pre-MSC successions. In the adjacent Pissouri basin a-planktonic layers occur; however, their origin and relation with the insolation index remains unclear (Kouwenhoven et al. 2006). In the coeval portion of the Sorbas basin planktonic foraminifera solely can be absent or strongly reduced during insolation minima, while benthic foraminifera show abundance maxima (Sierro et al. 2003). The authors speculated that the absence of planktonic foraminifera could be explained by the highly eutrophic, relatively toxic waters supplied to the photic zone during phase of intense mixing. This explanation could hold true for the Tokhni limestones; however the higher abundances of $U$.jafari and the heavier $\delta^{18} \mathrm{O}$ values also suggest that highly saline waters formed in the superficial layer could have prevented the proliferation of planktonic foraminifera. The advection of the newly formed highly saline waters to the sea floor, could have created unfit conditions for benthic foraminifera, too.

\subsubsection{Interval 3: 6.1 - MSC onset}

After 6.1 Ma planktonic and benthic foraminifera show a drop in abundance also in the shales, indicating increasingly stressed environmental conditions. However, the benthic assemblage composition remains the same and, together with the presence of shelf to bathyal cuspidariids bivalves in the sub-unit PK-B (Manzi et al. 2016), indicates that no remarkable paleodepth variation occurred in the proximity of the MSC onset, similarly to the Pissouri basin (Kouwenhoven et al. 2006). Conversely, calcareous nannofossil assemblages record important variations (Fig. 8). The
D. variabilis group, P.japonica, U.jafari, and Cd.leptoporus vanish, while R.antarctica, H.carteri and $U$.rotula show a remarkable abundance increase.

In this interval, the shales are still characterized by S.abies and R.minuta but not D.variabilis gr. This assemblage could suggest a shallower nutricline (being Discoaster spp. adapted to the lower photic zone, like the extant Florisphaera profunda; Flores et al. 2005, Stoll et al. 2007) and a moderate nutrient availability. Strong changes in sea surface salinity are also envisaged, since S.abies has been reported to be common to abundant between the gypsum beds of Stage 3 of Roveri et al. (2009), suggesting that it could be an euryhaline taxon (Polemi basin, Cyprus; Wade and Bown 2006). The continuous cyclic abundance of S.abies after 6.1 Ma confirms that the latter taxon shares only some ecological preferences with D.variabilis gr.

$C d$.leptoporus and U.jafari are replaced in the limestone beds by $R$.antarctica, a Reticulofenestra species characterized by closed central area. Such reticulofenestrids are also documented by Krhovsky et al. (1992) from diatom-rich Oligocene sediments from the Czech Republic (Uhercice Fm. and Dynow Marlstone), where they co-occur with fresh to brackish water diatom Melosira (Aulacosira) indicating that this taxon and its relatives could flourish in eutrophic environments with brackish to normal marine salinity.

In the topmost samples (across and above the MSC onset) planktonic foraminifera are nearly absent and calcareous nannofossils assemblages become increasingly dominated by S.abies, R.minuta, U.rotula, and to a lesser extent H.carteri. H.carteri is a meso- to eutrophic taxon (Ziveri et al. 2004), reported from eutrophic, hyposaline waters (Giraudeau 1992, Flores et al. 1997) and estuarine environments (Cachão et al. 2002). This taxon commonly occurs in the clays of the Upper Gypsum unit of Stage 3 of the Polemi basin together with Umbilicosphaera specimens that were interpreted as high salinity taxa (Wade and Bown 2006). In the Tokhni section high abundances of U.rotula occur both together and just above the H.carteri abundance peak, suggesting on the contrary that Umbilicosphaera spp. could be euryhaline and thrive in abnormal salinity waters. As for R.minuta, small reticulofenestrids are also particularly abundant in the sediments deposited at the beginning of the MSC in the Piedmont Basin, testifying their tolerance to stressed (Lozar et al. 2010, Violanti et al. 2013) and nearshore environments (Perch-Nielsen 1985), characterized by eutrophic surface waters and variable salinity. The as- 
sociation of U.rotula and R.minuta with H.carteri, the distinct negative $\delta^{18} \mathrm{O}$ values and the decline of the ${ }^{87} \mathrm{Sr} /{ }^{86} \mathrm{Sr}$ ratio (Fig. 8), which indicates a marked decreased influence of oceanic-derived waters, typical of the Stage 1 deposits (Roveri et al. 2014), suggest a preference of these taxa for lowered salinity. All this evidence indicates that the deposition of the conglomerate, coeval to the 6.1 Ma Mediterranean paleoceanographic step, marked an increasing riverine influence, both during insolation minima and maxima, reaching an acme at the MSC onset. The conglomerate is coeval to the slurry bed deposited in the Pissouri basin (Krijgsman et al. 2002, Manzi et al. 2016) and to a similar layer observed in the Fanantello borehole, which marks an increase of the terrigenous input into the Northern Apennine foredeep. Slope instability is also recorded in the Piedmont basin just below the LO of T.multiloba (Lozar et al. 2010, Violanti et al. 2013). These evidences suggest that a tectonic pulse, likely affecting the eastern and northern Mediterranean, could have contributed to trigger the paleoceanographic changes observed at ca. 6.1 Ma.

\subsection{Paleohydrologic implication for the Braarudosphaera bigelowii peak}

Braarudosphaera bigelowii has a very scattered but continuous occurrence along the geological record since the Early Cretaceous and shows sporadic blooms as that recorded at $26 \mathrm{~m}$ (up to $130 \mathrm{n} / \mathrm{mm}^{2}$ ) in the Tokhni composite section (Fig. 5). It has often been related to neritic environments (Bown et al. 2005, Bartol et al. 2008), to nutrient enrichment and/or low salinity waters, and is generally absent in oceanic settings (Peleo-Alampay et al. 1999, Kelly et al. 2003, Bartol et al. 2008). The affinity of B. bigelowii for hypohaline waters is well illustrated by its presence in the Black Sea, where surface waters have an average salinity of $17 \%$ to $18 \%$, and by its absence in the high-salinity waters of the Red Sea (Bukry 1974). This episodic occurrence suggests a sporadic and transient supply of fresher waters, either from enhanced runoff or from the connection with a brackish/fresh water body. The stratigraphic position of this abundance peak, three cycles below the $2^{\text {nd }}$ influx of G. scitula, dated at 6.102 Ma (correlated to cycle UA27 in the Abad composite, Sierro et al. 2001), suggests that these low salinity waters could have been sourced from the paleo-Black Sea, during the transient connection of the two basins approximating the Meotian/Pontian boundary (Grothe et al. 2014, Vasiliev et al. 2015).

\section{Conclusions}

The Tokhni composite section (Psematismenos basin, southern Cyprus Island) is characterized by the precession-paced alternation of red shales (precession minima/insolation maxima) and limestones (precession maxima/insolation minima). The phase relation between sedimentary cycles and precession cycles is based on cyclic variations of calcareous nannofossil taxa and $\delta^{18} \mathrm{O}$ values. The planktonic foraminifer and magnetostratigraphic events set the tuning of the sedimentary cycles to the $65^{\circ} \mathrm{N}$ summer insolation curve and to the Mediterranean pre-evaporitic reference sections (Sierro et al. 2001, Blanc-Valleron et al. 2002, Violanti et al. 2013) from 6.46 Ma up to the Messinian Salinity Crisis onset at 5.97 Ma. As previously observed in other pre-MSC successions, the onset of the crisis is approximated by: 1) the last recovery of planktonic and benthic foraminifera (Manzi et al. 2007, Manzi et al.2011, Violanti et al. 2013),2) the peaks of $U$.rotula and H. carteri (Lozar et al. 2010, Violanti et al. 2013) and 3) an increase of the fresh water input (based on ${ }^{87} \mathrm{Sr} /{ }^{86} \mathrm{Sr}$ values; Flecker et al. 2002, Roveri et a1. 2014). These events are recorded within an interval characterized by microbialitic and clastic carbonates (included in the "barre jaune" of Orszag-Sperber et al. 2009), a few meters below the clastic evaporites of the Kalavasos fm. (Manzi et al. 2016). This supports the interpretation that the evaporites of Tokhni do not represent the MSC beginning (Manzi et al. 2016), but instead the Stage 2 of Roveri et al. (2009), deposited after 5.60 Ma above the Messinian erosional surface.

The upper bathyal paleoenvironment, constructed for the Psematismenos basin, did not significantly change from ca. 6.5 Ma up to the MSC onset. On the other hand, remarkable paleoceanographic changes are documented at ca. 6.4 and 6.1 Ma, coeval to the uppermost major steps of the pre-MSC phase, and interpreted as increasingly stressed surface and bottom water conditions (Blanc-Valleron et al. 2002, Sierro et al. 2003, Kouwenhoven et al. 2006). It is hypothesized that from 6.4 Ma the increased runoff favoured the stratification of the water column and enhanced nutrients levels in bottom and surface waters at times of insolation maxima. Compared to the western Mediterranean, we observe a less severe oxygen reduction at the sea floor during insolation maxima, probably caused by the episodic formation of intermediate/deep waters. During insolation minima, excess evaporation in surface waters stimulated a vigorous mixing and we 
speculate that the absence of benthic and planktonic foraminifera was due to the elevated salinity. This indicates more extreme stressed conditions than in the Sorbas basin, where planktonic foraminifera solely are generally reduced in abundance (Sierro et al. 2003). After the deposition of the conglomerate at ca. 6.1 Ma, possibly related to a tectonic pulse, micropaleontologic assemblages were reduced in abundance and diversity in response to enhanced riverine influence. However, we note that a detectable decrease of the connection with the global ocean can be argued based on the reduction of the ${ }^{87} \mathrm{Sr} /{ }^{86} \mathrm{Sr}$ values at the MSC onset.

Acknowledgements. This research was funded by a MIUR (Ministero dell'Istruzione, dell'Università e della Ricerca, Italy) grant to M. Roveri (PRIN 2008). G. Gianelli and E.M. Selmo of the Physical and Earth Science Department of the University of Parma are thanked for processing the foraminifer samples and the $\mathrm{O}$ and $\mathrm{C}$ isotopic analysis, respectively. Iannis Panayides and Zomenia Zomeni of the Geological Survey of the Republic of Cyprus are acknowledged for their logistic support. A special thank is reserved to our colleagues Silvia Iaccarino, Maciej Babel and Andrea Irace for their help and for the discussion during the field trips in Cyprus. We are also grateful to an anonymous reviewer for the appreciated suggestions. This is ISMARCNR, Bologna, scientific contribution n. 1906.

\section{References}

Aubry, M.P., 1992. Late Paleogene calcareous nannoplankton evolution: a tale of climatic deterioration. In: Prothero, D. R., Berggren, W.A. (Eds.), Eocene-Oligocene Climatic and Biotic Evolution. Princeton University Press, pp. 272-309.

Ausin, B., Hernandez-Almeida, I., Flores, J.-A., Sierro, F.-J., Grosjean, M., Francés, G., Alonso, B. 2015. Development of coccolithophore-based transfer functions in the western Mediterranean sea: a sea surface salinity reconstruction for the last $15.5 \mathrm{kyr}$. Climate of the Past 11, 1635-1651.

Bagnall, P.S., 1960. The geology and mineral resources of the Pano Lefkara-Larnaca area. Geological Survey Department Cyprus Memoir 5, $116 \mathrm{p}$.

Bartol, M., Pavšič, J., Dobnikar, M., Bernasconi, S., 2008. Unusual Braarudosphaera bigelowii and Micrantholithus vesper enrichment in the Early Miocene sediments from the Slovenian Corridor, a seaway linking the Central Paratethys and the Mediterranean. Palaeogeography, Palaeoclimatology, Palaeoecology 267, 77-88.

Baumann, K.-H., Saavedra-Pellitero, M., Böckel, B., Ott, C., 2016. Morphometry, biogeography and ecology of Calcidiscus and Umbilicosphaera in the South Atlantic. Revue de Micropaléontologie 59(3), 239-251.

Blanc-Valleron, M.M., Pierre, C., Caulet, J.P., Caruso, A., Rouchy, J.M., Cespuglio, G., Sprovieri, R., Pestrea, S.,
Di Stefano, E., 2002. Sedimentary, stable isotope and micropaleontological records of paleoceanographic change in the Messinian Tripoli Formation (Sicily, Italy). Palaeogeography, Palaeoclimatology, Palaeoecology 185, 255286.

Boeckel, B., Baumann, K.-H., Henrich, R., Kinkel, H., 2006. Coccolith distribution patterns in South Atlantic and Southern Ocean surface sediments in relation to environmental gradients. Deep-Sea Research I 53, 1073-1099.

Boomer, I., Eisenhauer, G., 2002. Ostracod faunas as palaeoenvironmental indicators in marginal marine environments. In: Holmes, J., Chivas, A. (Eds.), The Ostracoda: Applications in Quaternary Research, Geophysical Monograph 131, 135-149.

Bown, P.R., 2005. Selective calcareous nannoplankton survivorship at the Cretaceous - Tertiary boundary. Geology 33, 653-656.

Bown, P. R., Young, J. R., 1998. Techniques. In: Bown, P. R. (Ed.), Calcareous Nannofossil Biostratigraphy. Kluwer Academic Publications, Dordrecht, Netherlands, pp. 1628.

Bukry, D., 1974. Coccoliths as paleosalinity indicators-evidence from the Black Sea. In: Degens, E.T., Ross, D. A. (Eds.), The Black Sea - Geology, chemistry, and biology: American Association Petroleum Geologists Memoirs 2, pp. 353-363.

Cachão, M., Drago, T., Silva, A.D., Moita, T., Oliveira, A., Naughton, F., 2002. The secret (estuarine?) life of Helicosphaera carteri: preliminary results. Journal of Nannoplankton Research 24, 76-77.

Chadima, M., Hrouda, F., 2006. Remasoft 3.0 a user-friendly paleomagnetic data browser and analyzer. Travaux Géophysiques XXVII, 20-21.

Dela Pierre, F., Bernardi, E., Cavagna, S., Clari, P., Gennari, R., Irace, A., Lozar, F., Lugli, S., Manzi, V., Natalicchio, M., Roveri, M., Violanti, D., 2011. The record of the Messinian salinity crisis in the Tertiary Piedmont Basin (NW Italy): the Alba section revisited. Palaeogeography, Palaeoclimatology, Palaeoecology 310, 238-255.

Dittert, N., Baumann, K.H., Bickert, T., Henrich, R., Huber, R., Kinkel, H., Meggers, H., 1999. Carbonate dissolution in the deep sea: methods, quantification and paleoceanographic application. In: Fischer, G., Wefer, G. (Eds.), Use of Proxies in Paleoceanography: Examples From the South Atlantic. Springer-Verlag, Berlin, pp. 255-284.

Drinia, H., Antonarakou, A., Tsaparas, N., Kontakiotis, G., 2007. Palaeoenvironmental conditions preceding the Messinian Salinity Crisis: a case study from Gavdos Island. Geobios 40, 251-265.

Dudley, W.C., Nelson, C.S., 1989. Quaternary surface-water stable isotope signal from calcareous nannofossils at DSDP Site 593, southern Tasman Sea. Marine Micropaleontology 13 (4), 353-373.

Flecker, R., de Villiers, S., Ellam, R.M., 2002. Modelling the effect of evaporation on the salinity- ${ }^{87} \mathrm{Sr} /{ }^{86} \mathrm{Sr}$ relationship in modern and ancient marginal-marine systems: the Mediterranean Messinian Salinity Crisis. Earth Planetary Science Letters 203, 221-233. 
Flores, J.-A., Sierro, F. J., Filippelli, G. M., Bárcena, M. A., Pérez-Folgado, M., Vázquez, A., Utrilla, R., 2005. Surface water dynamics and phytoplankton communities during deposition of cyclic late Messinian sapropels sequences in the western Mediterranean. Marine Micropaleontology 56, 50-79.

Flores, J.A., Sierro, F. J., Francés, G., Vázquez, A., Zamarreno, I., 1997. The last 100,000 years in the western Mediterranean: sea surface water and frontal dynamics as revealed by coccolithophores. Marine Micropaleontology 29, 351-366.

Flores, J. A., Sierro, F. J., Raffi, I., 1995. Evolution of the calcareous nannofossil assemblage as a response to the paleoceanographic changes in the eastern equatorial Pacific Ocean from 4 to $2 \mathrm{Ma}$ (Leg 138, Sites 849 and 852). Proceedings of the ODP, Scientific Results, vol.138. Ocean Drilling Program, College Station, TX, pp. 163-176.

Gass, T.M., 1960. The geology and mineral resources of the Dhali area. Geological Survey Department Cyprus Memoir 4, $116 \mathrm{p}$.

Gennari, R., Manzi, V., Angeletti, A., Bertini, A., Biffi, U., Ceregato, A., Faranda, C., Gliozzi, E., Lugli, S., Menichetti, E., Rosso, A., Roveri, M., Taviani, M., 2013. A shallow water record of the onset of the Messinian salinity crisis in the Adriatic foredeep (Legnagnone section, Northern Apennines). Palaeogeography, Palaeoclimatology, Palaeoecology 386, 145-164.

Gibbs, S., Shackleton, N., Young, J.R., 2004a. Orbitally forced climate signals in mid-Pliocene nannofossil assemblages. Marine Micropaleontology 51, 39-56.

Gibbs, S., Shackleton, N., Young J. R., 2004b. Identification of dissolution patterns in nannofossil assemblages: A high-resolution comparison of synchronous records from Ceara rise, ODP Leg 154, Paleoceanography 19, PA1029.

Giraudeau, J., 1992. Distribution of recent nannofossils beneath the Benguela system: southwest African continental margin. Marine Geology 108, 219-237.

Grothe, A., Sangiorgi, F., Mulders, Y.R., Vasiliev, I., Reichart, G.-J., Brinkhuis, H., Krijgsman, W., 2014. Black Sea desiccation during the Messinian Salinity Crisis: fact or fiction? Geology 42, 563-566.

Hermoso, M., Horner, T. J., Minoletti, F., Rickaby, R.E. M., 2014. Constraints on the vital effect in coccolithophore and dinoflagellate calcite by oxygen isotopic modification of seawater. Geochimica et Cosmochimica Acta 141, 612-627.

Hilgen, F.J., Krijgsman, W., 1999. Cyclostratigraphy and astrochronology of the Tripoli diatomite formation (preevaporite Messinian, Sicily, Italy). Terra Nova 11, 16-22.

Iaccarino, S. M., Premoli Silva, I., Biolzi, M., Foresi, L. M., Lirer, F., Turco, E., Petrizzo, M.R. 2007. Practical manual of Neogene Planktonic Foraminifera. International School on Planktonic Foraminifera. VI course: Neogene. Perugia.

Imai, R., Farida, M., Sato, T., Iryu, Y., 2015. Evidence for eutrophication in the northwestern Pacific and eastern Indian oceans during the Miocene to Pleistocene based on the nannofossil accumulation rate, Discoaster abundan- ce, and coccolith size distribution of Reticulofenestra. Marine Micropaleontology 116, 15-27.

Jorissen, F. J., 1987. The distribution of benthic foraminifera in the Adriatic Sea. Marine Microplaeontology 12, $21-$ 48.

Kaiho, K., 1994. Benthic foraminiferal dissolved-oxygen index and dissolved-oxygen levels in the modern ocean Geology 22, 719-722.

Kameo, K., 2002. Late Pliocene Caribbean surface water dynamics and climatic changes based on calcareous nannofossil records. Palaeogeography, Palaeoclimatology, Palaeoecology 179, 211-226.

Kelly, D.C., Norris, R. D., Zachos, J.C., 2003. Deciphering the paleoceanographic significance of Early Oligocene Braarudosphaera chalks in the South Atlantic. Marine Micropaleontology 49, 49-63.

Kirschvink, J.L., 1980. The least-squares line and plane and the analysis of palaeomagnetic data. Geophysical Journal of the Royal Astronomical Society 62, 699-718.

Kouwenhoven, T.J., Hilgen, F.J., van der Zwaan, G.J., 2003. Late Tortonian-early Messinian stepwise disruption of the Mediterranean-Atlantic connections: constraints from benthic foraminiferal and geochemical data. Palaeogeography, Palaeoclimatology, Palaeoecology 198, 303-319.

Kouwenhoven, T.J., Morigi, C., Negri, A., Giunta, S., Krijgsman, W., Rouchy, J.-M., 2006. Paleoenvironmental evolution of the eastern Mediterranean during the Messinian: constraints from integrated microfossil data of the Pissouri Basin (Cyprus). Marine Micropaleontology 60, 17-44.

Kouwenhoven, T.J., Seidenkrantz, M.-S., van der Zwaan, G.J., 1999. Deep-water changes: the near-synchronous disappearance of a group of benthic foraminifera from the late Miocene Mediterranean. Palaeogeography, Palaeoclimatology, Palaeoecology 152, 259-281.

Krhovsky, J., Adamova, J., Hladikova, J, Maslowska, H., 1992. Paleoenvironmental changes across the Eocene/ Oligocene boundary in the Zdanice and Pouzdrany units (Western Carpathians, Czechoslovakia): the long-term trend and orbitally forced changes in calcareous nannofossil assemblages. Proceeding IV INA Conference, Knihovnicka ZPN, 14 b, 2, p. 105-187.

Krijgsman,W., Blanc-Valleron, M.-M., Flecker, R., Hilgen, F. J., Kouwenhoven, T. J., Merle, D., Orszag-Sperber, F., Rouchy, J.-M., 2002. The onset of the Messinian salinity crisis in the Eastern Mediterranean Pissouri Basin, Cyprus. Earth and Planetary Science Letters 194, 299310.

Krijgsman, W., Hilgen, F. J., Raffi, I., Sierro, F. J., Wilson, D.S., 1999a. Chronology, causes and progression of the Mediterranean salinity crisis. Nature 400, 652-655.

Krijgsman, W., Langereis, C.G., Zachariasse, W.J., Boccaletti, M., Moratti, G., Gelati, R., Iaccarino, S., Papani, G., Villa, G., 1999b. Late Neogene evolution of the TazaGuercif Basin (Rifian Corridor, Morocco) and implications for the Messinian Salinity Crisis. Marine Geology $153,147-160$. 
Krijgsman, W., Langereis, C. G., 2000. Magnetostratigraphy of the Zobzit and Koudiat Zarga sections (Taza-Guercif basin, Morocco): implications for the evolution of the Rifian Corridor. Marine and Petroleum Geology 17, 359371.

Laskar, J., Robutel, P., Joutel, F., Gastineau,M., Correia, A., Levrard, B., 2004. A long-term numerical solution for the insolation quantities of the Earth. Astronomy and Astrophysics 428, 261-285.

Lozar, F., Violanti, D., Dela Pierre, F., Bernardi, E., Cavagna, S., Clari, P., Irace, A., Martinetto, E., Trenkwalder, S., 2010. Calcareous nannofossils and foraminifers herald the Messinian Salinity Crisis: the Pollenzo section (Alba, Cuneo; NW Italy). Geobios 43, 21-32.

Lozar, F., Violanti, D., Bernardi, E., Dela Pierre, F., Natalicchio, M. Identifying the onset of the Messinian salinity crisis: a reassessment of the biochronostratigraphic tools (Piedmont Basin, NW Italy). This volume.

Manzi, V., Gennari, R., Hilgen, F., Krijgsman, W., Lugli, S., Roveri, M., Sierro, F. J., 2013. Age refinement of the Messinian salinity crisis onset in the Mediterranean. Terra Nova 25, 315-322.

Manzi, V., Roveri, M., Gennari, R., Bertini, A., Biffi, U., Giunta, S., Iaccarino, S., Lanci, L., Lugli, S., Negri, A., Riva, A., Rossi, M.E., Taviani, M., 2007. The deep-water counterpart of the Messinian Lower Evaporites in the Apennine foredeep: the Fanantello section (Northern Apennines, Italy). Palaeogeography, Palaeoclimatology, Palaeoecology 251, 470-499.

Manzi, V., Lugli, S., Roveri, M., Dela Pierre, F., Gennari, R Lozar, F., Natalicchio, M., Schreiber, B.C., Taviani, M. Turco, E., 2016. The Messinian salinity crisis in Cyprus: a further step toward a new stratigraphic framework for Eastern Mediterranean. Basin Research 28, 207-236.

Manzi, V., Gennari, R., Lugli, S., Roveri, M., Schreiber, B.C., 2011. The Messinian "Calcare di Base" (Sicily, Italy) revisited. Geological Society of America Bulletin 123, 347-370.

McArthur, J.M., Howarth, R.J., Bailey, T.R., 2001. Strontium isotope stratigraphy: LOWESS version 3: best fit to the marine Sr-isotope curve for 0-509 Ma and accompanying look-up table for deriving numerical age. Journal of Geology 109, 155-170.

McIntyre, A., McIntyre, R., 1971. Coccolith concentrations and differential solution in oceanic sediments. In: Funnell, B.M., Riedel, W.R. (Eds.), The Micropaleontology of Oceans. Cambridge University Press, London, pp. 253-261.

Murray, J.W., 2006. Ecology and Application of Benthic Foraminifera. Cambridge University Press. $426 \mathrm{pp}$.

Nijenhuis, I.A., Schenau, S.J., Van der Weijden, C.H., Hilgen, F. J., Lourens, L. J., Zachariasse, W. J., 1996. On the origin of upper Miocene sapropelites: a case study from the Faneromeni section, Crete (Greece). Paleoceanography $11,633-645$.

Orszag-Sperber, F., Caruso, A., Blanc-Valleron, M. M., Merle, D., Rouchy, J.M., 2009. The onset of the Messinian salinity crisis: insights from Cyprus sections. Sedimentary Geology 217, 52-64.
Pantazis, T.M., 1967. The geology and mineral resources of the Pharmakas-Kalavasos area. Geological Survey Department Cyprus Memoir 8, 190 p.

Peleo-Alampay, A. M., Mead, G. A., Wei, W., 1999. Unusual Oligocene Braarudosphaera-rich layers of the South Atlantic and their paleoceanographic implications. Journal of Nannoplankton Research 21, 17-26.

Perch-Nielsen, K., 1985. Cenozoic calcareous nannofossils. In: Bolli, H. M., Saunders, J.B., Perch-Nielsen, K. (Eds.), Plankton Stratigraphy. Cambridge University Press, Cambridge, pp.427-554.

Pérez-Folgado, M., Sierro, F.J., Barcena, M.A., Flores, J. A., Vazquez, A., Utrilla, R., Hilgen, F. J., Krijgsman, W., Filippelli, G.M., 2003. Western versus eastern Mediterranean paleoceanographic response to astronomical forcing: a high-resolution microplankton study of precession-controlled sedimentary cycles during the Messinian. Palaeogeography, Palaeoclimatology, Palaeoecology 190, 317-334.

Pestrea, S., Blanc-Valleron, M.M., Rouchy, J. M., 2002. Les assemblages de diatomées des niveaux infra-gypseux du Messinien de Méditerranée (Espagne, Sicile Chypre). Geodiversitas 24, 543-583.

Raffi, I., Mozzato, C., Fornaciari, E., Hilgen, F. J., Rio, D., 2003. Late Miocene calcareous nannofossil biostratigraphy and astrobiochronology for the Mediterranean region. Micropalaeontology 49, 1-26.

Renaud, S., Ziveri, P., Broerse, A.T. C., 2002. Geographical and seasonal differences in morphology and dynamics of the coccolithophore Calcidiscus leptoporus. Marine Micropaleontology 46, 363-385.

Robertson, A.H.F., Eaton, S., Follows, E.J., Payne, A.S., 1995. Depositional processes and basin analysis of Messinian evaporites in Cyprus. Terra Nova 7, 233-253.

Rohling, E.J., Marino, G., Grant, K.M., 2015. Mediterranean climate and oceanography and the periodic development of anoxic events (sapropels). Earth-Science Reviews 143, 62-97.

Roveri, M., Gennari, R., Lugli, S., Manzi, V., 2009. The terminal carbonate complex: the record of sea-level changes during the Messinian salinity crisis. GeoActa 8 , 57-71.

Roveri, M., Lugli, S., Manzi, V., Gennari, R., Schreiber, B.C., 2014. High-resolution strontium isotope stratigraphy of the Messinian deep Mediterranean basins: implications for marginal to central basin correlation. Marine Geology 349, 113-125.

Sierro, F. J., Flores, J. A., Francés, G., Vazquez, A., Utrilla, R., Zamarreño, I., Erlenkeuser, H., Barcena, M. A., 2003. Orbitally-controlled oscillations in planktic communities and cyclic changes in western Mediterranean hydrography during the Messinian. Palaeogeography, Palaeoclimatology, Palaeoecology 190, 289-316.

Sierro, F. J., Hilgen, F. J., Krijgsman, W., Flores, J. A., 2001. The Abad composite (SE Spain): A Mediterranean reference section for the Mediterranean and the APTS. Palaeogeography, Palaeoclimatology, Palaeoecology 168, 141169. 
Stoll, H. M., Shimizu, N., Archer, D., Ziveri, P., 2007. Coccolithophore productivity response to greenhouse event of the Paleocene-Eocene thermal maximum. Earth Planetary Science Letters 258, 192-206.

Triantaphyllou, M.V., Tsaparas, N., Stamatakis, M., Dermitzakis, M.D., 1999. Calcareous nannofossil biostratigraphy and petrological analysis of the preevaporitic diatomaceous sediments from Gavdos Island, southern Greece. Neues Jahrbuch für Geologie und Pälontologie Monatshefte 161-178.

Van der Zwaan, G. J., 1982. Paleoecology of late Miocene Mediterranean foraminifera. Utrecht Micropaleontological Bulletin 25, $201 \mathrm{p}$.

Vasiliev, I., Reichart, G.-J, Grothe, A., Sinninghe Damsté, J.P., Krijgsman, W., Sangiorgi, F., Weijer, J. W.H., van Roij, L., 2015. Recurrent phases of drought in the upper Miocene of the Black Sea region. Palaeogeography, Palaeoclimatology, Palaeoecology 423, 18-31.

Violanti, D., Lozar, F., Natalicchio, M., Dela Pierre, F., Bernardi, E., Clari, P., Cavagna, S., 2013. Microfossili tolleranti condizioni di stress ambientale del Messiniano pre-evaporitico di Pollenzo (Piemonte, Italia nord-occidentale). Bollettino della Società Paleontologica Italiana 52, 45-54.

Wade, B.S., Bown, P.R., 2006. Calcareous nannofossils in extreme environment: the Messinian Salinity Crisis, Po- lemi Basin, Cyprus. Palaeogeography Palaeoclimatology Palaeoecology 233, 271-286.

Zijderveld, J.D.A., 1967. A.C. demagnetization of rocks: Analysis of results. In: Collinson, D.W., Creer, K.M., Runcorn, S.K. (Eds.), Methods in paleomagnetism. Elsevier, New York, 254-256 p.

Ziveri, P., Baumann, K.-H., Böckel, B., Bollmann, J., Young, J.R., 2004. Present day coccolithophore biogeography of the Atlantic Ocean. In: Thierstein, H.R., Young, J.R. (Eds.), Coccolithophores: From Molecular Processes to Global Impact. Springer Verlag, pp. 529-562.

Ziveri, P., de Bernardi, B., Baumann, K.-H., Stoll, H.M., Mortyn, P.G., 2007. Sinking of coccolith carbonate and potential contribution to organic carbon ballasting in the deep ocean. Deep Sea Research Part II. Topical Studies in Oceanography 54 (5-7), 659-675.

Ziveri, P., Stoll, H., Probert, I., Klaas, C., Geisen, M., Ganssen, G., Young, J., 2003. Stable 'vital effects' in coccolith calcite. Earth and Planetary Science Letters 210, 137-149.

Manuscript received: May 15, 2016

Revised version accepted: December 5, 2016 